OECDpublishing

G20/OECD Effective Approaches For Implementing the G20/OECD High-Level Principles on SME Financing

Miriam Koreen

André Laboul

Naima Smaini

OECD SME and

Entrepreneurship Papers No. 9 


\section{OECD SME AND ENTREPRENEURSHIP PAPERS}

This paper is published under the responsibility of the Secretary-General of the OECD. The opinions expressed and the arguments employed herein do not necessarily reflect the official views of OECD member countries.

The publication of this document has been authorised by Lamia Kamal-Chaoui, Director of the Centre for Entrepreneurship, SMEs, Regions and Cities,

This document, as well as any data and map included herein, are without prejudice to the status of or sovereignty over any territory, to the delimitation of international frontiers and boundaries and to the name of any territory, city or area.

OECD Papers on SMEs and Entrepreneurship are published on http://www.oecd-ilibrary.org/papers

You can copy, download or print OECD content for your own use, and you can include excerpts from OECD publications, databases and multimedia products in your own documents, presentations, blogs, websites and teaching materials, provided that suitable acknowledgment of OECD as source and copyright owner is given. All requests for commercial use and translation rights should be submitted to rights@ oecd.org. 


\title{
G20/OECD Effective Approaches for Implementing the G20/OECD High-Level Principles on SME Financing
}

\author{
Miriam Koreen \\ André Laboul \\ Naima Smaini
}

OECD SME and

Entrepreneurship Papers No. 9 September 2018 


\begin{abstract}
This paper identifies effective approaches adopted by countries to implement the G20/OECD High-Level Principles on SME Financing, welcomed by the G20 Leaders at their Antalya Summit in 2015. It draws on participating countries' replies to dedicated surveys. In total, 41 countries participated in the process, including 16 G20 countries.
\end{abstract}

JEL codes: L26, G32

Keywords: SME finance; SME financing; SME finance policies; SME financing policies; G20; 


\section{Executive Summary}

1. This document contains the final report on Effective Approaches for Implementing the G20/OECD High Level Principles on SME Financing. It is transmitted to G20 Finance Ministers and Central Bank Governors.

2. In November 2015, at their Summit in Antalya, G20 Leaders welcomed and agreed on the G20/OECD High-Level Principles on SME Financing, which were developed by the OECD, together with other relevant international organisations (IOs), at the request of G20 Finance Ministers and Central Bank Governors. In their 2015 Antalya Action Plan, G20 Leaders called for work to identify effective approaches to facilitate the implementation of the Principles, and in 2016 they reiterated their support for their effective implementation. The latter was also supported by G20 Finance Ministers and Central Bank Governors at their February, April and July 2016 meetings.

3. Building on the experience from recent exercises carried out to develop effective approaches to support the implementation of other G20/OECD High-Level Principles, a survey-based process was adopted. Two surveys were conducted through the OECD Working Party on SMEs and Entrepreneurship (WPSMEE) and the G20/OECD Task Force on Institutional Investors and Long-Term Financing (Task Force), the first relating to Principles 1, 2, 3 and 5, and the second covering Principles 4, 6, 8, 9, 10 and 11.

4. The results of the first survey were presented in an interim report submitted to the WPSMEE and Task Force for comments during their April and May 2017 meeting, respectively. A revised report was submitted to the WPSMEE during its October 2017 session and to the Task Force by written communication, also in October 2017. The results of the second survey were presented to the WPSMEE at its meeting in April 2018 and to the Task Force at its meeting in May 2018. With regard to policy approaches for enhancing SME financial skills (Principle 7), a dedicated survey was launched via the OECD International Network on Financial Education (OECD/INFE) and its working group on financial education for MSMEs in March 2017, building on recent work in this area. A preliminary version of the results on Principle 7 was presented at the $8^{\text {th }}$ OECD/INFE Technical Committee meeting in New Delhi in November 2017. The final version was circulated to OECD/INFE full members through written process in February 2018.

5. A draft consolidated report was then circulated to both the WPSMEE and the Task Force in May 2018, and discussed by WPMSEE and Task Force Delegates during a joint meeting on 23 May 2018. The report was submitted to the Infrastructure Working Group under written procedure in June 2018.

6. The report identifies a set of approaches for the implementation of the Principles, based on the results of the surveys. The executive summary sets out the key findings from the exercise. A summary table of the full results of the exercise can be found in Annex A. 
Identify SME financing needs and gaps and improve the evidence base (Principle 1)

7. Governments recognise the importance of building the evidence base for policy making in the area of SME finance and take steps to identify the financing needs and challenges of their SME population. In all participating countries, a framework is in place to collect quantitative data on SME finance. Central banks and statistics offices generally play a major role in the collection of data on bank loans, while countries tend to rely on the data provided by business associations as regards investments in SMEs by private equity and venture capital firms.

8. The large majority of countries also gather evidence on SMEs which do not have access to mainstream financial services and products through surveys. Governments rely on public bodies for such exercises, too, with only a few countries collecting data from or through private sector providers. Very few countries collect information on the specific products SMEs do not have access to, though.

9. Relevant stakeholders are involved in the assessment of SME financing gaps through institutionalised consultative bodies like an SME committee or panel, or through more informal ad hoc consultations (which seems more frequent). This assessment is generally published, often through periodic or dedicated online publications, by the central bank, the ministry of finance or the SME agency.

\section{Strengthen SME access to traditional bank financing (Principle 2)}

10. Guarantees appear to be the most widespread tool to strengthen SME access to traditional bank financing. Most guarantee schemes target specific segments, which receive preferential conditions. In particular, innovative and growth-oriented SMEs, young and women entrepreneurs, as well as start-ups, are a priority for many guarantee programmes. A number of countries have also put in place measures to support the securitisation of SME loans, in order to free balance sheets and favour an increase in SME lending by spreading the risk across more players. In most countries, these measures aim at creating an enabling and conducive framework, including through the creation of registers to increase the availability and transparency of information.

11. Numerous countries have put in place simplified or accelerated insolvency procedures for SMEs. They have also taken measures to enhance the timeliness in insolvency proceedings, while ensuring that the insolvency framework provides creditors with a range of opportunities to monitor the progress of an insolvency administration in which they have an interest. This is generally coupled with a digitisation of the procedure, intended to make it easier and quicker to deal with. Countries have also strived to improve insolvency competencies in courts, in particular by putting in place specialised courts or judges.

\section{Enable SMEs to access diverse non-traditional financing instruments and channels (Principle 3)}

12. On the demand side, various platforms (generally online) and awareness seminars are in place to increase the knowledge of SME owners and managers of all available financing options.

13. On the supply side, most countries provide equity to SMEs via a government or government-related institution, or via subscriptions to funds. Initiatives to increase SME access to asset-based financing instruments seem to have focused on factoring and supply-chain finance. A majority of countries have also taken steps to encourage retail investors to invest in SME financial markets, often in the form of tax incentives. 


\section{Promoting financial inclusion for SMEs (Principle 4)}

14. Young entrepreneurs, SMEs located in remote areas and women entrepreneurs are the most widespread priority sub-segments. Programmes targeting specific SME populations are more rarely evidence-driven: while most countries can provide a breakdown of the evidence and data collected on SMEs which do not have access to mainstream financial products and services by sector and size, only a few countries can provide a breakdown by location or owner demographics. For instance, while 26 countries have designed policies targeting SMEs located in remote areas, only 6 countries collect data disaggregated by location. There appears to be room to further build the evidence base as regards access to finance by specific sub-segments.

15. Most countries have taken steps to support the development of Fintech solutions as a way of increasing the financial inclusion of SMEs. Generally, countries have created an enabling legal and regulatory framework. On the demand side, governments have provided awareness and training workshops, or online courses. Fintech appears to be viewed as an opportunity by policy makers and supervisors, who aim to accompany the development of Fintech solutions, and mitigate related risks (as regards investor protection and data privacy, in particular).

Design regulation that supports a range of financing instruments for SMEs, while ensuring financial stability and investor protection (Principle 5)

16. A majority of countries have conducted a review of the legal and regulatory framework to identify measures restricting SME access to finance. Such reviews are generally complemented by processes aiming at considering the potential impact of relevant upcoming laws and regulations on SME access to finance at the drafting stage. A few countries have undertaken tax reforms with the explicit aim of supporting the diversification of financing instruments for SMEs. These reforms generally take the form of fiscal incentives for certain types of investments (e.g. investments in venture capital funds).

\section{Improving transparency in SME finance markets (Principle 6)}

17. Digitalisation appears to be an effective way to improve access to the data contained in business or credit registries. It can also help increase the coverage and relevance of these data, by making submission and update processes simpler and less costly. There remain important differences in the level of consultation fees across countries though, which may reflect different views as regards the importance of free access to such information and transparency for an efficient functioning of markets.

18. Commercial credit reporting companies are more frequent than public credit registries. Half of the countries which have commercial credit reporting companies have put in place an oversight of these companies. The nature of the oversight and the authority in charge vary across countries. The reflection on the risks which come with the benefits such companies can provide to market players, and the most efficient way of mitigating and managing them, is still ongoing in many countries.

\section{Enhance SME financial skills and strategic vision (Principle 7)}

19. Very few countries measure the financial skills of SME owners and managers in order to identify their strengths and weaknesses. Financial education initiatives for SMEs target a range of skills, including basic knowledge of financial concepts, understanding traditional and alternative financial products, as well as accessing and managing credit. Most initiatives deliver financial education via workshops, trainings, printed booklets and 
online information, but mobile phone applications, online videos and e-learning platforms are also emerging in some countries.

20. National strategies often target the SME population as a whole. Nonetheless, in some countries, not-for-profits and, less frequently, governments tailor programmes to specific segments such as young entrepreneurs, women entrepreneurs, indigenous and immigrant entrepreneurs, or start-ups.

21. Empirical evidence on the effectiveness of financial education and business training programmes remains limited.

\section{Adopting principles of risk sharing for publicly supported SME finance instruments (Principle 8)}

22. Nearly all responding countries have a public financial institution which contributes to national objectives regarding SME access to finance. It generally operates alongside or through private sector players. Banks largely remain the most important partner of public authorities, with other financial institutions (non-bank financial institutions like leasing or factoring companies, or equity funds), playing a less prominent role.

23. Guarantees to financing operations undertaken by SMEs with commercial players are the most widespread type of collaboration between private-sector financial institutions and public financial institutions (the public financial institution provides guarantees in twenty-six countries). A few countries offer risk-sharing instruments other than guarantees (generally first-loss risk cover). In slightly more than a third of countries which have a public financial institution, the public financial institution co-invests alongside private-sector players.

\section{Encouraging timely payments in commercial transactions and public procurement (Principle 9)}

24. When it comes to tackling the cash flow issues SMEs may face as a result of payment delays, the majority of governments tend to focus on payments by public bodies, while they seem reluctant to restrict the contractual freedom of private firms to pay invoices. There are numerous initiatives in that area, from prompt payment codes to tracking systems which can provide detailed information on payment delays by public bodies. Some of these mechanisms have proved particularly effective in swiftly and substantially reducing payment delays.

\section{Designing public programmes for SME finance which ensure additionality, cost effectiveness and user-friendliness (Principle 10)}

25. Ensuring the financial and economic additionality of public programmes is a guiding principle in almost all countries. There are different interpretations of what these concepts imply, though. There appears to be room to improve the methodology when assessing the additionality of programmes. Likewise, while a large majority of countries report that a framework is in place to ensure that the costs associated with the implementation of public programmes do not outweigh their benefits, less than a third conduct a formal assessment. Regarding user-friendliness, governments recognise the importance of raising SME awareness of programmes for which they may be eligible, and do so through dedicated websites or awareness campaigns. 
Monitoring and evaluating public programmes to enhance SME finance (Principle 11)

26. There is a contrast between governments' recognition of the importance of evaluating programmes to improve SME access to finance and corresponding evaluation methodologies and procedures. Very few countries conduct evaluations based on a rigorous methodology and thorough metrics in a systematic manner. There also appears to be scope to increase the extent to which the findings of evaluations are taken into account when designing new programmes. However, most countries do publish evaluations, generally online. 


\section{Introduction}

27. In November 2015, at their Summit in Antalya, G20 Leaders welcomed and agreed on the G20/OECD High-Level Principles on SME Financing, which were developed by the OECD, together with other relevant international organisations (IOs), at the request of G20 Finance Ministers and Central Bank Governors.

28. The Principles are voluntary and non-binding, and addressed to G20 and OECD members and other interested economies, and can apply to diverse circumstances and different economic, social and regulatory environments (see Box 1). They provide broad guidelines for the development of cross-cutting policy strategies, efforts to benchmark policies and the assessment of current initiatives on SME financing at the local, national and international levels. The Principles also aim to encourage dialogue, exchange of experiences and coordination, including regulatory coordination, among stakeholders in SME finance, among which policy makers, financial institutions, research institutions and SME management, on how to enhance SME access to finance and increase SMEs' contribution to resilient and inclusive growth.

29. In their 2015 Antalya Action Plan, G20 Leaders called for work to identify effective approaches to facilitate the implementation of the Principles, and in 2016 they reiterated that call. Work on effective approaches was also supported by G20 Finance Ministers and Central Bank Governors at their February, April and July 2016 meetings.

30. Building on the experience from recent exercises carried out to develop effective approaches to support the implementation of other G20/OECD High-Level Principles, including those on long-term investment financing by institutional investors ${ }^{1}$ and on financial consumer protection ${ }^{2}$, a survey-based process was adopted. In November 2016, a first survey was launched that considered a subset of related Principles, i.e. Principles 1, 2, 3 and 5, which cover key framework issues for SME finance. The survey was conducted through the G20/OECD Task Force on Institutional Investors and Long-term Financing (hereafter the Task Force) and the OECD Working Party on SMEs and Entrepreneurship (hereafter the WPSMEE).

\footnotetext{
${ }^{1}$ See Report on Effective Approaches to Support Implementation of the G20/OECD High-Level Principles on Long-term Investment Financing by Institutional Investors, submitted to the G20 Brisbane Summit in November 2014.

${ }^{2}$ See Update Report on the Work to Support the Implementation of the G20 High-Level Principles on Financial Consumer Protection and Annex, submitted to the G20 Saint Petersburg Summit in September 2013, as well as Effective Approaches to Support the Implementation of the remaining G20 High-Level Principles on Financial Consumer Protection and Addendum, submitted to G20 Finance Ministers and Central Bank Governors at their meeting in Cairns in September 2014.
} 


\section{Box 1. G20/OECD High-Level Principles on SME Financing}

1. Identify SME financing needs and gaps and improve the evidence base.

2. Strengthen SME access to traditional bank financing.

3. Enable SMEs to access diverse non-traditional bank financing instruments and channels.

4. Promote financial inclusion for SMEs and ease access to formal financial services, including for informal firms.

5. Design regulation that supports a range of financing instruments for SMEs, while ensuring financial stability and investor protection.

6. Improve transparency in SME finance markets.

7. Enhance SME financial skills and strategic vision.

8. Adopt principles of risk sharing for publicly supported SME finance instruments.

9. Encourage timely payments in commercial transactions and public procurement.

10. Design public programmes for SME finance which ensure additionality, cost effectiveness and user-friendliness.

11. Monitor and evaluate public programmes to enhance SME finance.

31. Twenty-five countries, including 10 G20 countries, completed the first survey: Austria, Belgium, Canada, Chile, China, the Czech Republic, Denmark, Estonia, France, Germany, Greece, Ireland, Israel, Italy, Japan, Latvia, Lithuania, Mexico, Portugal, the Russian Federation, Spain, Sweden, Switzerland, Turkey and the United Kingdom. The results of this first survey were presented in an interim report submitted for comments to the WPSMEE and Task Force during their April and May 2017 meeting, respectively. A revised report was submitted to the WPSMEE during its October 2017 session and to the Task Force by written communication, also in October 2017.

32. The revised report was submitted along with a draft second survey, relating to the remaining Principles, i.e. Principles 4, 6, 8, 9, 10 and 11.

33. After taking Delegates' comments on the draft survey into account, the second survey was circulated to the Task Force on 30 November 2017, and to the WPSMEE on 1 December 2017.

34. Thirty-eight countries, including 14 G20 countries, completed the second survey: Australia, Austria, Belgium, Canada, Chile, China, Colombia, Costa Rica, the Czech Republic, Denmark, Egypt, Estonia, Finland, France, Germany, Greece, Ireland, Israel, Italy, Japan, Korea, Latvia, Lithuania, Mexico, the Netherlands, New Zealand, Norway, Poland, Portugal, Romania, the Russian Federation, South Africa, Spain, Sweden, Switzerland, Turkey, the United Kingdom and the United States. A report on the results of the second survey was submitted to the WPSMEE during its April 2018 meeting and to the Task Force during its May 2018.

35. With regard to policy approaches for enhancing SME financial skills (Principle 7), a dedicated survey was launched via the OECD International Network on Financial Education (OECD/INFE) and its working group on financial education for MSMEs in 
March 2017, building on recent work in this area $^{3}$. Thirteen authorities from twelve countries and economies submitted replies: Angola, Austria, Canada, the Czech Republic, Estonia, Hong Kong - China, India, Indonesia, Japan, Portugal, Spain and Turkey. A preliminary version of the results on Principle 7 was presented at the 8th OECD/INFE Technical Committee meeting in New Delhi in November 2017. The final version was circulated to OECD/INFE full members through written process in February 2018. Given the limited number of responses, the section on Principle 7 does not distinguish between common and other approaches on the one hand and innovative approaches on the other hand. It also draws on other work of the OECD/INFE on the financial education of MSMEs, including a stock taking survey conducted in $2015^{4}$.

36. A draft consolidated report, covering all principles and based on the results of all surveys, was discussed during a meeting gathering delegates from both the WPSMEE and the Task Force in May 2018.

37. Comments were taken into account in a draft final report, which was submitted to the Infrastructure Working Group under written procedure in June 2018.

38. A table summarising the full results of the exercise can be found in Annex A. The three questionnaires can be found in an Addendum to this document.

\section{Definitions of common, other and innovative approaches}

39. "Common approaches" are approaches which are adopted by a majority of responding countries.

40. "Other approaches" are approaches which are adopted by less than a majority of countries.

41. "Innovative approaches" are approaches adopted by only a few countries (sometimes only one country), which show some novelty in the approach adopted to implement the principle and potential for replication.

42. Policies are qualified as effective when they are considered to be effective by implementing countries, and when experience, results and evidence suggest that this is the case.

43. The effective approaches identified in the report are not comprehensive, illustrative and non-binding. They are intended as examples to assist policy makers and other relevant stakeholders in their policy work to improve SME access to finance.

\footnotetext{
${ }^{3}$ See OECD/INFE High Level Principles on National Strategies for Financial Education, endorsed by G20 Leaders at their Los Cabos Summit in June 2012.

${ }^{4}$ The survey fed into the OECD working paper "Financial Education for MSMEs and Potential Entrepreneurs".
} 
Report on Effective Approaches for Implementing the G20/OECD HighLevel Principles on SME Financing 


\title{
Principle 1 - Identify SME financing needs and gaps and improve the evidence base
}

\begin{abstract}
As a first step in developing a strategy to enhance SME access to finance, governments should assess the extent to which SMEs' financing needs are met and where gaps exist, in cooperation with relevant stakeholders, including central banks and financial supervisory authorities, financial and research institutions and SME representatives. This requires a strong evidence base and a better understanding of SME financing needs and challenges by public authorities and financial suppliers. ${ }^{5}$ Efforts should be placed on improving statistical information on SME financing, particularly in developing economies, where a lack of reliable evidence constrains policy design, implementation and assessment. This calls for cooperation at the national and international levels (including through an expansion of the OECD Scoreboard on Financing SMEs and Entrepreneurs) to increase transparency regarding definitions, improve the comparability of data and indicators, within and across countries ${ }^{6}$, facilitate international benchmarking ${ }^{7}$ and regulatory coordination, and shed light on outstanding financing gaps and issues.
\end{abstract}

\section{Common and other approaches}

44. Governments recognise the importance of building the evidence base for policy making in the area of SME finance and take steps to identify the financing needs and challenges of their SME population. In all the countries surveyed a framework is in place to collect quantitative data on SME finance.

45. As regards data on bank loans, the central bank and statistics office generally play a major role in data collection efforts. Data collected almost always include SME loan stocks and flows, interest rates and non-performing loans rates. Less frequently, data is collected on loan rejection rates, collateral requests, drawdowns, overdraft utilisation,

5 Evidence on SME financing, including micro data and micro analysis is needed for informed policy discussion; the evaluation of policies; monitoring the implications of financial reforms on SMEs' access to finance and for a better understanding by financial suppliers of SME financing needs. Evidence on financing needs and gaps by firm size and stage in the firm life cycle is especially important to tailor policy strategies. In this regard, regular quantitative demand-side surveys can represent an important source of information, but their harmonisation at the national, regional and international level should be encouraged to improve the quality of information and cross-country comparability.

6 At the international level, comparison of data on SME finance is significantly hampered by differences in definitions and methodology.

7 Strengthening the ability to document differences in SME access to finance across countries can shed light on policy experiences and facilitate the exchange and adaptation of good policy practices. 
loan terms and conditions, direct government loans, government guaranteed loans, restructured loans or export credit guarantees.

46. Data collection is done through reporting exercises to these public bodies, as well as through surveys. While reporting is due on a regular basis (with basic data collected on a monthly basis), surveys are conducted either on a regular basis or based on needs (before designing a new programme for example). Their frequency can vary substantially from one type of survey to another, as well as from one country to another. That frequency can be linked to the scope of the survey. For instance, some countries conduct resource-intensive surveys on a pluri-annual basis, and lighter surveys in the years these resource-intensive surveys are not conducted.

47. For data on funds received by SMEs from private equity and venture capital firms, or business angels, most countries rely on relevant or specialised business associations. These associations tend to collect data through surveys, which are generally conducted on an annual basis, with some data also collected on a bi-annual or quarterly basis.

48. Other sources used to collect both quantitative and qualitative data include bank associations, economic research institutes and research centres, development banks (for all countries which have one), and guarantee institutions. Resort to data from commercial providers and non-governmental organisations is rarely mentioned.

49. Breakdowns collected almost always include size, sector and location. Age of firm and form of ownership are collected by some countries, albeit less frequently. Collection of data on owner characteristics is also less frequent, sometimes due to privacy laws or confidentiality concerns. However, a number of countries do collect data on the gender or age of the owner, as well as other characteristics, like the birth country of the owner for example.

50. A large majority of surveyed countries also gather evidence on SMEs which do not have access to mainstream financial services and products ${ }^{8} 29$ out of 38). Surveys appear to be an effective tool to gather such evidence, with around two-thirds of countries conducting a survey, or several surveys.

51. Breakdowns by sector and size appear to be the most prevalent (with 14 countries which can provide a breakdown by size - generally measured by number of employees or turnover, and 14 countries which can provide a breakdown by sector). Breakdowns by other dimensions are less widespread (only seven countries can provide a breakdown by location and six a breakdown by owner demographics).

52. While there is a certain variety in the bodies through which data is collected (whether through surveys or not), public bodies are considered to be effective data providers, with only a few countries resorting to evidence collected by the private sector.

\footnotetext{
${ }^{8}$ The paragraphs on evidence gathered by countries on SMEs which do not have access to mainstream financial services and products draw on countries' replies to related survey questions under Principle 4. They are grouped with information gathered under Principle 1, since replies to these questions both relate to identifying SME financing needs and gaps and improving the evidence gap. Under Principle 1, countries have provided information on the data they collect on the funding provided to SMEs, while under Principle 4 countries have provided information on how they gather evidence on SMEs which do not have access to mainstream financial services and products.
} 
The two most prevalent bodies involved are the central bank or supervisor (mentioned by 18 countries) and the statistics office (mentioned by 12). Other public bodies involved include government agencies (in eight countries), ministries (in five countries), the development or public bank (in five countries). Six countries also leverage data collected by international organisations.

53. Very few countries collect evidence on the specific products SMEs do not have access to, with the information gathered through survey processes relating to "access to finance" in general. Among the countries which do not collect data on the products SMEs have access to or not, one country however organises informal roundtables with SMEs on an ad hoc basis, in order to better understand the financing products to which they have sufficient and insufficient access.

54. When it comes to gathering comparative evidence from other countries and regions to assess SME financing trends and conditions, nine countries mention the OECD Scoreboard on Financing SMEs and Entrepreneurs, with six out of nine relying on the Scoreboard only. Most Eurozone countries also use data produced by the European Central Bank (in particular data collected through the European Central Bank/European Commission Survey on the Access to Finance of Enterprises and the ECB Bank Lending Survey), as well as data produced by Eurostat. Survey replies also suggest that other Eurozone countries are considered as the relevant benchmark for these countries.

55. The OECD SME Financing Scoreboard appears as the main tool through which surveyed countries contribute to international efforts to improve the comparability of statistical data on SME finance. Out of 22 countries which answered this question, 16 countries mentioned the Scoreboard and 12 the Scoreboard only. Countries which participate in other initiatives to improve the comparability of statistical data on SME finance are generally European Union countries which participate in European Union initiatives, including through the SME Envoys Network.

56. A large majority of countries report that they involve relevant stakeholders in the assessment of SME financing gaps. These include the main public bodies (central bank, ministry of finance and statistics office) as well as relevant business associations (banks association, private equity and venture capital association, and sometimes also SME association). Some countries have an SME committee or panel which meets on a regular basis (generally three or four times a year) to discuss SMErelated questions, including access to finance, and serves as a consultative body. For most countries though, the consultation process seems to be more informal, and conducted on an ad hoc, rather than regular basis. Consultations sometimes also include research institutes or experts.

57. Likewise, most countries report that they publish the government assessment of SME financing needs and trends. This publication takes various forms. Periodic or ad hoc publications by the central bank, ministry of finance or SME agency are widespread, with publication often occurring on the respective websites of these bodies. Less frequently, some countries also publish press releases or organise press conferences to make the main highlights of this assessment known to the general public.

\section{Innovative approaches}

58. A novel approach adopted to gather data on funding provided to SMEs by private equity and venture capital firms, or business angels, is a partnership between public 
bodies (central bank, ministry of finance and/or statistics office) and private equity, venture capital or angel capital business associations, to conduct surveys on the state of SME financing in these segments. This represents an interesting combination of access to the relevant companies on the one hand and technical capacity on the other hand (since these public bodies have technical capacities, in the statistics field in particular, that very few business associations have to the same extent), in a sector which is not submitted to the same type of regulation as the banking sector, and whose players do not submit regular reportings.

Selected effective approaches to identify SME financing needs and gaps and improve the evidence base, based on survey results

- Collecting quantitative data on SME finance through reportings to, and surveys conducted by, public bodies (central bank, statistics office, etc.).

- Collecting data on funds received by SMEs from private equity and venture capital firms, or business angels, through the relevant business associations.

- Partnership between public bodies (central bank, ministry of finance and/or statistics office) and private equity, venture capital or angel capital business associations, to conduct surveys on the state of SME financing in these segments.

- Gathering comparative evidence from other countries and regions through the OECD Scoreboard on Financing SMEs and Entrepreneurs.

- Involving relevant stakeholders in the assessment of SME financing gaps through an institutionalised SME committee or panel, or through ad hoc consultations.

- Publishing the government assessment of SME financing needs and trends online 


\section{Principle 2 - Strengthen SME access to traditional bank financing}

As a main source of external finance for most small businesses, efforts to improve banks' capacity to lend to SMEs should be pursued. Measures may include credit guarantees, securitisation, credit insurance and adequate provisioning for loan losses. Risk mitigation measures should be strengthened, making use of new technologies and mechanisms for underwriting risk. Effective and predictable insolvency regimes should ensure creditor rights while supporting healthy companies and offering a second chance for honest entrepreneurs. Likewise, SMEs should be afforded credit on reasonable terms and with appropriate consumer protection measures in place. Policy makers should consider enabling SMEs to use a broader set of assets beyond fixed collateral, such as movable assets, to secure loans. The feasibility of expanding the use of intangibles as collateral should be carefully considered, to ease access to lending particularly by knowledge-based companies, while taking into account potential risks.

The use of credit information should also be enabled to improve risk management for lenders and access for borrowers.

\section{Improving banks' capacity to lend to SMEs}

\section{Common and other approaches}

59. Out of 25 countries which completed the survey, 23 provide direct policy support to bank lending to SMEs. Guarantees to SME loans appear to be the most widespread instrument, with guarantee funds mentioned by almost all countries, and as the main pillar of support for SME lending. Guarantees are generally capped, but this cap can be quite high, and a few countries guarantee up to $100 \%$ of the amount of the loans. Most countries have one guarantee fund providing guarantees for SME loans. In a few countries, various institutions are involved, depending on the sector in which the SME operates for instance. Most guarantee funds target specific segments, which receive preferential conditions. In particular, innovative and growth-oriented SMEs, young and women entrepreneurs, as well as start-ups are a priority for a number of guarantee programmes.

60. Incentives to foster SME lending by commercial banks are less widespread than direct support policy measures (eight countries do not have such incentives). For European Union countries, incentives include the SME supporting factor introduced in the Capital Requirements Directive IV, under which the capital requirement for loans to SMEs is reduced by the application of a 0.7619 multiplier. A similar multiplier is applied in some non-EU countries. Other incentives include a lower reserve requirement ratio and different terms for liquidity provision for countries which have a minimum amount of SME loans or share of SME loans in their total loan portfolio.

61. In 14 countries the government has put in place or is in the process of introducing measures to support the securitisation of SME loans. In most cases, these measures aim at creating an enabling and conducive framework, through legal and regulatory reform or the creation of registers increasing the availability and transparency of information. In 
countries which have a public financial institution, it generally participates actively in the securitisation market, so as to support its growth. One country has worked to increase awareness and skills in that area by the means of in-house and external seminars and trainings to help market participants understand securitisation and actively participate in the market. These seminars are complemented by online information.

62. As regards the effectiveness of measures, only six countries could reply that the measures implemented had proven effective. In other countries the measures were just being put in place, or it was too early to tell whether they had been effective.

\section{Innovative approaches}

63. Some innovative approaches intend to make the credit approval process more transparent to SMEs. In one country, banks have an obligation to provide SMEs with a standardised credit report and with their credit rating, based on a common methodology. Another country has put in place a credit review office, providing a credit appeals process for SMEs. The credit review office is meant to help SMEs who have had an application for credit of up to three million euros declined or reduced by participating banks, but feel that they have a viable business proposition. It also looks at cases where borrowers feel that the terms and conditions of their existing loan, or a new loan offer, are unfairly onerous or have been unreasonably changed to their detriment.

64. As regards securitisation, in one country the government supported the creation of a securitisation company, on the initiative of the central bank, and in partnership with commercial banks. This company issues guaranteed debt securities backed by loan portfolios, including SME and midcap loan portfolios. These securities can be used as collateral in capital markets operations. The company rating system established by the central bank plays a major role in the good functioning of this scheme.

\section{Insolvency regime}

\section{Common and other approaches}

65. Nineteen countries have introduced measures to streamline insolvency procedures and reduce the related administrative burden. These measures tend to put in place simplified or accelerated procedures for SMEs, thus aiming at making them more manageable for entrepreneurs and small businesses, which may not have internal legal resources or access to external legal advice.

66. Eighteen countries have taken measures to enhance timeliness in insolvency proceedings. Overall, the measures established clear timelines for the various steps of insolvency proceedings (in particular the filing of claims, the creditors' meeting and the court hearing) or shortened these timelines. This was often coupled with a digitisation of the procedure through online forms, meant to make it easier and quicker to deal with. Only three countries have conducted evaluations of the effectiveness of measures to enhance timeliness in insolvency proceedings, one through a government evaluation body, one through an independent consultancy and one through a published research article.

67. Sixteen countries have taken steps to ensure that the insolvency framework provides creditors with a range of opportunities to receive information and to monitor the progress of an insolvency administration in which they have an interest. Seven of these countries have put in place an online insolvency register. While it generally provides 
real-time access to submissions made by other parties to the proceedings, reports of the insolvency administrator and issued judgements of the court, there are some variations across countries in both the extent of the information contained in the online register and the extent of the access provided (i.e. who can access the register and when the information it contains can be accessed).

68. One country has put in place an insolvency bulletin in the form of an electronic newsletter which provides information about liquidations, renegotiations and reorganizations conducted and undertaken. This bulletin is considered as the only valid form to notify the parties. Any person can have access to the newsletter and review all the proceedings undertaken.

69. Seventeen countries have taken measures to enhance insolvency competencies in courts. Out of these 17 countries, 14 have put in place specialised courts or judges, and two have provided specific training to judges.

70. A few countries allow debt discharge, to facilitate a second chance for nonfraudulent entrepreneurs. However, the timelines vary substantially from one country to another. In one country, debtors subject to bankruptcy are discharged from their debts after 12 months, with the restriction extended beyond 12 months only when there has been some wrongdoing. In another country, however, early debt discharge for insolvent entrepreneurs implies that, while the general rule is that a discharge can only be obtained after six years, an early discharge is available after three years, provided that the debtor covers the costs of the proceedings and discharges at least $35 \%$ of outstanding debts. Some countries report that no such regime is in place. In one of them, an insolvent entrepreneur cannot request any credit from banks for seven years.

\section{Innovative approaches}

71. The most favourable regime in terms of debt discharge, under which debtors are discharged of their debts after 12 months, also includes some innovative features intended to allow a non-fraudulent entrepreneur to quickly start a new activity. In particular, during bankruptcy, a debtor may keep their tools of trade and a vehicle to enable them to continue to work. They may also set up a new business whilst bankrupt, but must disclose their full name, and if obtaining credit over a limit, must disclose their bankruptcy status. A bankrupt individual cannot be a company director, but s/he can seek leave of the court to take on or continue a directorship.

\section{Collateral: common and other approaches}

72. Among measures to reduce the costs and time for filing and registering security interests, a few countries have digitised this registration, so that it can be made in a few minutes. Digital registers also appear as an effective way of publicising the existence of security rights on assets to creditors, purchasers and the general public.

73. Only three countries reported having taken steps to facilitate the use of nonfixed and intangible assets (such as patents, trademarks and other intellectual property) to secure loans. Two countries have undertaken evaluations to assess the benefits, costs and risks implied by the use of non-fixed and intangible assets to secure loans. 
Selected effective approaches to strengthen SME access to traditional bank financing, based on survey results

- Providing government guarantees to SME loans, with specific programmes targeting priority segments (women entrepreneurs, young entrepreneurs, start-ups, etc.).

- Supporting the securitisation of SME loans, including by creating an enabling and conducive legal and regulatory framework or by putting in place a register increasing the availability and transparency of information.

- Making the credit approval process more transparent to SMEs, for instance by providing them with a standardised credit report and with their credit rating, based on a standardised methodology.

- Making insolvency procedures simpler and quicker for SMEs, including by digitising the process (through an online register allowing online submission of forms and realtime consultations by the parties along the process) or by establishing clear timelines for the various steps of insolvency proceedings.

- Enhancing insolvency competencies in courts through specialised courts, judges or the provision of specific training to judges.

- Digitising the registration of security interests; digital registers can also be an effective way of publicising the existence of security rights on assets to creditors, purchasers and the general public. 


\title{
Principle 3 - Enable SMEs to access diverse non-traditional financing instruments and channels
}

\begin{abstract}
Recognising the complementary nature of the role of banks and other financing channels, access to a sufficiently broad range of SME financing instruments is desirable in order to obtain the form and volume of financing best suited to SMEs specific needs and the stage of the firm lifecycle. Multiple and competing sources of finance for SMEs should be supported, and efforts should be made to increase entrepreneurs' awareness of the available financing options through targeted outreach initiatives. The development of alternative financial instruments for SMEs should also aim to attract a wider range of investors, including institutional investors ${ }^{9}$, and to enhance their understanding of SME markets. Asset-based finance ${ }^{10}$ could be fostered to enable young and small firms to access working capital on rapid and flexible terms, as well as supply chain and trade finance to support their integration in global value chains. Alternative forms of debt ${ }^{l 1}$ could be cultivated to enable SMEs to invest, expand and restructure. Adequate policy attention should go to the development of hybrid tools ${ }^{12}$ and equity instruments ${ }^{13}$ to strengthen SMEs' capital structure and boost investment in innovative start-ups and high-growth SMEs ${ }^{14}$. Special consideration should be given to venture and private equity financing, including capital for seed, early and later stage investments, as well as to trade finance instruments.
\end{abstract}

\section{Increasing entrepreneurs' awareness of the available financing options}

\section{Common and other approaches}

74. Online platforms providing comprehensive and tailored information in order to increase the knowledge of SME owners and managers of all available financing options are common. Information programmes and campaigns are widespread. They can

9 See also the G20/OECD High level Principles of long term investment financing by institutional investors and their related effective approaches.

10 Asset based finance includes, for example, asset-based lending, factoring, purchase order finance, warehouse receipts, and leasing.

11 Alternative forms of debt include corporate bonds, private placements, direct lending by non-bank institutions, and peer-to-peer lending.

12 Hybrid instruments include subordinated loans and bonds, silent participations, participating loans, profit participation rights, convertible bonds, bonds with warrants, and mezzanine finance

13 Equity instruments comprise venture capital, business angel investing, other private equity instruments, specialised platforms for public listing of SMEs and equity-based crowdfunding

14 The existence of appropriate channels for exit can help increase the attractiveness of these instruments for investors. 
take different forms and be undertaken by various stakeholders, depending on the country context. Examples include awareness actions conducted by the public financial institution in partnership with the chamber of commerce, in the form of seminars, in the capital and in the regions. They are sometimes accompanied by tailored consulting services. In one country, free regional advisory "clinics" give SMEs the opportunity to meet with a corporate finance expert to discuss, in private and on a one-to-one basis, their individual funding plans. Another one has launched an SME Business Navigator, which is a free web tool for entrepreneurs willing to start a business, which provides them with helpful information, including on financing options. To make the SME Business Navigator particularly accessible, mobile applications are available.

\section{Innovative approaches}

75. Innovative approaches go beyond raising awareness or providing consulting services, and play an active role in matching SMEs with funds or investors. This can be achieved through an online platform matching start-ups and investor needs, a business network created by the government or a concierge service offering free, customised advice to SMEs and connecting them to funding and support programmes that will help them grow their business through innovation. Such matching can also be achieved through "Meet the Funder Events" providing businesses with information on and access to a range of funding providers. Speakers address how businesses should approach the funding process and companies have an opportunity to network with funding providers.

76. One country has also put in place a referral regime whereby SMEs rejected for credit by the largest banks must be offered a referral to a designated, online finance platform.

\section{Broadening the base of SME investors: common and other approaches}

77. Governments in 15 countries have taken action to encourage retail investors to invest in SME financial markets. In two thirds of these countries, this took the form of tax incentives. Tax reductions granted for investments in SMEs are always capped, but this cap varies substantially across countries. Eligibility for the tax reduction may also depend on the fulfilment of a certain number of criteria, which can include the age of the SME, its location or the way the shares were acquired (must be via a crowdfunding platform for example).

\section{Asset-based finance}

\section{Common and other approaches}

78. Only a few countries report having taken action to support the development of asset-based lending for SMEs, in some cases because such reforms are not considered to be needed because an enabling framework is already in place. A few countries have promoted factoring of electronically recorded monetary claims, while industry efforts aim at developing systems that enable different electronic monetary claim recording institutions to electronically transfer recorded monetary claims to each other. Some others have put in place a framework supporting supply chain finance, for instance by allowing lending between non-financial institutions if there is a commercial link between them. A few countries have set up supply chain finance electronic platforms, accompanied with access to assistance and training. 


\section{Innovative approaches}

79. One country, after setting up an online platform providing a registration service for accounts receivable pledges and transfers, finance leases, inventory and warehouse receipts pledges, as well as a public notification system for movable assets financing, is working on a service platform for inventory finance. With the authorisation of the owner, lenders could have access to the warehouse system for owner's inventory historical record. Information related to the collateral situation would also be available during the effective period of pledge. The platform would also enable the simultaneous exchange of commodities ownership information.

\section{Alternative forms of debt: corporate bonds and private placements: common and other approaches}

80. Fifteen countries have introduced measures to enhance the public issuance, trading and clearing conditions of corporate debt securities. Nine report that rules are in place to provide for private placements of corporate securities. In 17 countries, the legal and regulatory framework allows non-listed SMEs to issue corporate bonds, and this can generally be done on the same terms as for listed companies, which include the preparation of a prospectus, unless an exemption is granted. Such exemptions are granted for issuances below a certain cap or addressed to sophisticated investors only for instance.

\section{Hybrid instruments: common and other approaches}

81. A few countries support the provision of mezzanine finance to SMEs through mezzanine funds targeting SMEs, and with the objective of supporting the development of commercial mezzanine finance markets. These funds can be managed by the public financial institution for countries which have one, or funding can be provided to a privately managed fund extending mezzanine finance to SMEs. One country has put in place a micro-mezzanine fund, which provides silent partnerships for SMEs with smaller funding needs.

\section{Equity finance}

\section{Common and other approaches}

82. In 21 countries, a government or government-related institution makes direct equity investments in SMEs. The public financial institution is generally in charge of these equity investments, through a series of different funds. They are generally co-investments alongside private investors. In most cases, this is combined with indirect equity investments through funds of funds.

83. A few countries offer targeted initiatives to improve investor-readiness of startups and SMEs, generally through accelerators or incubators providing them with training (finance and pitching training, in particular), as well as mentoring, coaching and networking opportunities.

84. In most countries, seed and early stage investors, such as venture capitalists and business angels, are not subject to licensing norms, solvency or funding requirements, accounting requirements or investment regulations. Likewise, very few jurisdictions have restrictions on investments in seed and early stage ventures by banks, insurance companies or retail collective investment. Restrictions tend to affect pension funds more, 
with eight countries mentioning restrictions in pension funds' investments in seed and early stage ventures.

85. Support to equity investments through tax incentives is widespread. However, foreigners are eligible for these incentives in only eight countries, and in two of these countries only if they are resident, while for two others only EU or EEA citizens are eligible.

86. As regards listings, rules and requirements are adapted to small equity issuers in 13 countries.

\section{Innovative approaches}

87. In a few countries support is provided to SMEs which are or will be listed in the form of mentoring/coaching, with the objective of helping them comply with listing requirements. Such support can even be mandatory until one year after the listing.

\section{Crowdfunding: common and other approaches}

88. A clear regulatory framework is in place in $\mathbf{1 3}$ countries. However, this framework generally covers only equity crowdfunding. Various limitations apply to both the issuer and the investor. The issuer is submitted to a number of information and publication obligations. The amount the issuer can raise can also be limited. Investors are limited in the amounts they can invest, and may be obliged to seek the advice of an investment adviser. Caps vary substantially across countries.

89. Campaigns to increase awareness on crowdfunding options are conducted in various forms, including seminars, crowdfunding days, and brochures on crowdfunding. Some countries focus on the risks associated with equity crowdfunding for investors, and carefully monitor the activity of crowdfunding platforms.

Selected effective approaches to enable SMEs to access diverse non-traditional financing instruments and channels, based on survey results

- Increasing awareness of SME owners and managers of all available financing options through a combination of online platforms, information programmes and seminars, delivered in various locations across the country.

- Matching SMEs with funds or investors through an online platform or through dedicated events.

- Improving the investor-readiness of start-ups and SMEs through accelerators or incubators providing them with training as well as mentoring, coaching and networking opportunities.

- Putting in place a referral regime whereby SMEs rejected for credit by the largest banks must be offered a referral to a designated, online finance platform. 


\section{Principle 4. Promote financial inclusion for SMEs and ease access to formal financial services, including for informal firms}

Policy should aim to maximise the number of SMEs which have access to and use mainstream financial services and products at a reasonable cost. Financial inclusion is an important tool to reduce informality, and national financial inclusion strategies should include reviewing the legal and regulatory framework of the financial sector; defining a public intervention strategy and identifying appropriate delivery instruments; and ensuring the existence of tools for groups excluded from the formal banking sector. Microfinance schemes should be given adequate attention, particularly in developing countries, as a means to enhance entrepreneurs' access to small amounts of funding at an affordable cost.

\section{Common and other approaches}

90. Most countries have implemented numerous measures in the field of financial inclusion, although they do not necessarily fall under a financial inclusion strategy. Only six countries have a financial inclusion strategy. SME access to finance is an important dimension of countries' work in the area of financial inclusion, with 21 countries signalling that SMEs are among targets in the financial inclusion strategy or in measures in the area of financial inclusion (out of 24 concerned). These are reviewed regularly in 17 countries, including seven countries in which the review is conducted annually.

91. As regards policies aiming at increasing the access to finance of specific subsegments, priority segments are generally young entrepreneurs, SMEs located in remote areas and women entrepreneurs (with specific policies targeting these subsegments in around two-thirds of surveyed countries). Half as many countries have launched programmes targeting senior entrepreneurs and entrepreneurs with disabilities. Migrants businesses are a priority in ten countries. Some programmes combine components and target rural women entrepreneurs for example.

92. Policies targeting SMEs located in remote areas are generally a component of regional development programmes, aiming at supporting the development of regions lagging behind, and ensuring fair access across the country. In that regard, there seems to be a contrast between the high number of countries which design policies aiming at improving the access to finance of SMEs located in remote areas and the low number of countries collecting data disaggregated on SMEs which do not have access to mainstream financial services and products by location (26 vs seven - cf supra). There appears to be scope to further build the evidence base as regards SME access to finance across territories.

93. A number of countries also mention programmes targeting the unemployed, graduates or veterans. On the former, entrepreneurship is viewed by numerous 
governments as one way of helping some categories of the unemployed population get a job, in particular youth or people who are in long-term unemployment.

94. Common policies to improve the access to finance of these sub-segments include access to a guarantee, subsidies and various exemptions (tax exemptions, simplified licensing, etc.). These programmes are sometimes complemented by demand-side measures like the provision of advisory or consultancy services, trainings or access to networks.

95. Most governments provide public support to microfinance institutions (MFIs) (25 out of 38). In some countries, support is provided at the local level. Policies to support MFIs include the provision of funding to be channelled to priority segments (either directly through a public financial institution or indirectly through partner financial institutions), access to guarantees, subsidies or loss cover, sometimes complemented by technical assistance. Such support is generally accompanied by an encouragement to serve financially excluded SMEs (in 20 out of 25 countries). MFIs do not appear to be a significant channel to serve informal SMEs in surveyed countries.

96. More assessment of the effectiveness of measures to enhance access to finance through MFIs appears to be warranted. While 13 countries declare that the measures undertaken have proven effective, the metrics used to measure this effectiveness (increase in lending or number of loans extended by MFIs, amount disbursed, decrease in the interest rate charged or higher survival rate of funded micro-businesses) could be improved. Four countries replied that the effectiveness of measures was unknown since no evaluation had been conducted, while one replied that it was too early to assess the impact of the measures undertaken.

97. Only one country has observed that access to microfinance loans increases chances of formalisation of SMEs, while eight replied that it was not the case, and four that this was unknown since no evaluation had been conducted.

98. A large majority of countries have taken steps to support the development of Fintech solutions as a way of increasing SME access to finance (27 out of 38). In most of these countries (19 out of 27) related measures consisted of or included the creation of an enabling legal and regulatory framework. Some countries have also created "desks", "portals" or similar platforms to favour a continuous dialogue between Fintech companies or entrepreneurs willing to create a Fintech company and supervisors. The provision of awareness and training workshops or online courses on crowdfunding is also mentioned. One country has supported the creation of an association of Fintech companies. Overall, Fintech appears to be viewed as an opportunity by policy makers and supervisors, who aim to accompany the development of Fintech solutions while mitigating related risks (as regards investor protection and data privacy in particular).

\section{Innovative approaches}

99. As regards policies targeting specific segments (young entrepreneurs, women entrepreneurs, senior entrepreneurs, entrepreneurs with disabilities, migrants businesses and SMEs located in remote areas), a few countries have gone beyond the common policies mentioned supra (guarantee, subsidy, etc.) to offer programmes specifically designed for the targeted segment. Based on a thorough assessment to identify the specific challenges the segment faces, a multi-dimensional programme involving various stakeholders is structured so as to address these specific challenges. These tailored 
programmes appear particularly effective in helping targeted segments overcome the challenges they face to access suitable forms of finance. Likewise, in designing and implementing programmes targeting women entrepreneurs, one country has opted for partnerships with national women's organisations, as well as with the International Labour Organisation (ILO), so as to both build on the knowledge of these organisations on the women entrepreneurs segment and leverage their networks to optimise the outreach of the programmes.

100. Among measures to support MFIs, one country has opted for the provision of credit reports by the credit bureau at a lower price, in order to help them in their credit scoring. To benefit from this option, MFIs must commit to report data on their customers to the credit bureau, so as to increase its comprehensiveness and usefulness to all users.

101. One country has conducted an econometric evaluation using propensity matching to assess government support to MFIs, which showed that the programme had reached the target group and succeeded in helping them catch up.

102. In a few countries, support for the development of Fintech solutions to increase SME access to finance through the creation of an enabling legal and regulatory framework took innovative forms. A few jurisdictions have resorted to regulatory sandboxes which operate under different conditions depending on the country. In one country, for instance, the supervisor introduced industry wide licensing exemptions to allow eligible Fintech businesses to test certain specified services for up to 12 months without a financial services or credit license. Regulatory sandboxes appear to have been quite effective in favouring a variety of initiatives in the field of Fintech. One country has partnered with the private sector to develop an early payment and supply chain finance solution to strengthen SME access to liquidity.

Selected effective approaches to promote financial inclusion for SMEs and ease access to formal financial services, including for informal firms, based on survey results

- Including relevant breakdowns (by gender, by location, etc.) in the collection of data on SMEs which do not have access to mainstream financial services and products, so as to design evidence-based policies targeting priority segments.

- Developing specific programmes for priority segments, based on a thorough assessment of the specific challenges and obstacles they face. 


\section{Principle 5 - Design regulation that supports a range of financing instruments for SMEs, while ensuring financial stability and investor protection}

Policy makers and regulatory authorities should ensure that regulation is designed and implemented that facilitates SMEs' access to a broad range of financing instruments without compromising financial stability and investor protection, and enables a return on investment. Regulatory certainty is needed to ensure a predictable and stable operating environment for firms and investors. The combined effects of different regulations should also be considered. Regulations should be proportionate to the risks of different financing instruments. Efforts should be made to avoid undue administrative burdens (including through digitalisation), cut red tape and facilitate bankruptcy resolutions. Particularly in the equity space, flexibility provided to SMEs should be compatible with investor protection, integrity of market participants, corporate governance and transparency. Good corporate governance in SMEs should be encouraged, to enhance their access to equity markets. Legal, tax and regulatory frameworks (including tax policies which provide incentives to encourage both debt and equity financing) should contribute to foster diverse sources of finance. ${ }^{15}$ International regulatory coordination can serve to promote cross-border financing for SMEs. ${ }^{16}$

\section{Common and other approaches}

103. A large number of surveyed countries (21) have conducted a review of the legal and regulatory framework to identify measures restricting SME access to mainstream financial services and products. Importantly, in all these countries except one, the results of this review fed into policies or resulted in amendments to the legal or regulatory framework.

104. Such reviews of the existing stock are generally complemented by processes aiming at considering the potential impact of relevant upcoming laws and regulations on SME access to finance at the drafting stage, before such laws and regulations are adopted and implemented.

105. Consultative mechanisms with the private sector are in place to assess regulation affecting the business environment and design regulatory reform in 19 countries. Among these countries there, is an almost even distribution between two types of consultation processes. On the one hand, some countries conduct consultations only before issuing new regulations. This consultation generally takes the form of a public consultation. On the other hand, some countries have institutionalised consultative bodies, like an SME council or committee, including representatives of the private sector, which meet on a

\footnotetext{
15 This may be of particular importance to attract private investors to early stage investments.

${ }^{16}$ In addition, international exchange of experiences on regulation for new sources of finance can be particularly beneficial.
} 
regular basis to discuss various questions related to SMEs ${ }^{17}$, and are consulted on draft regulations and regulatory reforms. These consultative bodies tend to have subcommittees or working groups specialised on specific themes, which generally include access to finance or regulation. A few countries mention the creation of working groups before drafting and issuing regulations. These working groups can include members of academia, as independent parties complementing the views of interested stakeholders.

106. Regulatory coordination seems to take place at regional level rather than at an international level. For European Union countries, regulatory coordination takes place through participation in the work of relevant European Union agencies. In addition, the Capital Markets Union project appears as the main work stream under which European countries improve international regulatory coordination as a means to promote cross-border financing. Likewise, countries in Latin America mention initiatives under the Pacific Alliance.

107. Tax policies are examined to ensure that they contribute to fostering diverse sources of finance for businesses in twelve countries out of the seventeen which answered that question. These assessments are often based on expert opinions or broad considerations. Nine countries have in recent years undertaken tax reforms with the explicit aim of supporting the diversification of financing instruments for SMEs. These tax reforms target both SMEs and investors. They generally take the form of fiscal incentives for certain types of investments, e.g. investments in venture capital funds investing in SMEs.

108. Very few countries have adopted policies to encourage good corporate governance in SMEs or taken action to raise awareness about good corporate governance principles by start-ups and SMEs approaching capital markets. Efforts in that area are focused on listed companies, with SMEs being reached by these efforts when they are listed. Some countries mention initiatives intended to improve SMEs' accounting standards, so as to improve their financial transparency.

Selected effective approaches to design regulation that supports a range of financing instruments for SMEs, while ensuring financial stability and investor protection, based on survey results

- Considering the potential impact of relevant new laws and regulations on SME access to finance.

- Reviewing relevant existing laws and regulation to assess their impact on SME access to finance.

- Consulting the private sector and all relevant stakeholders when assessing the impact of existing or contemplated regulation on SME access to finance, through a public consultation, an ad hoc and dedicated working group, or through the consultation of an institutionalised consultative body like an SME council or an SME committee.

- Examining tax policies to ensure that they contribute to fostering diverse

${ }^{17}$ Please see supra regarding the involvement of relevant stakeholders in the assessment of the SME financing gaps. 


\section{Principle 6. Improve transparency in SME finance markets}

Information asymmetries in finance markets should be minimised to increase market transparency, encourage greater investor participation and reduce financing costs for SMEs. Information infrastructures for credit risk assessment should aim to support an accurate evaluation of the risk in SME financing. To the extent possible and appropriate, credit risk information should be standardised and made accessible to relevant market participants and policy makers to foster both debt and non-debt SME financing instruments. Accessibility of this information at the international level should be supported to foster SMEs' cross-border activities and participation in global value chains.

\section{Common and other approaches}

109. Almost all countries have a business registry, which is considered to be an effective tool for overcoming information asymmetries. The registry is generally available online. It can be held by different bodies, including chambers of commerce, and either at the national or at the local level (regional chambers of commerce for example).

110. Most countries have undertaken measures to enhance the accessibility of the business registry (31 out of 38 , and one is exploring undertaking such measures). The main measure undertaken is the digitisation of the registry, so as to make it available online. In some countries, this includes not only the possibility of consulting the registry, but also the possibility to register a business online, and sometimes in a very short time, one day for example. Digitisation appears to be an effective way of improving access to the data contained in the registry.

111. While a few countries have made all information available for free, the norm seems to be that basic information (date of incorporation, address, etc.) is accessible for free, while access to other information (financial statements in particular) requires the payment of a fee. A few countries have aimed at increasing accessibility by reducing the cost to consult the register. This is generally achieved by decreasing the cost of each consultation, but can also take the form of allowing a number of free consultations. For example, in one country consultations cost USD 1, while in another one every business is allowed 30 free consultations (which do not include the possibility to copy or save however). Overall, there seems to remain important differences in the level of fees across countries.

112. A large number of countries (24 out of 38) have undertaken measures to increase the comprehensiveness and quality of the information provided by the business registry (and one country is exploring doing so). For instance, one country offers a free online service to upload electronic copies of financial statements and proxy circulars.

113. Around a third of surveyed countries have a public credit registry which covers SMEs (and one country is currently establishing a public credit registry). A large 
number of these registries comply with the General Principles for Credit Reporting, at least partially. Almost all contain both negative and positive information (12 out of 14 , and the country which is currently establishing a public credit registry will establish a registry which contains both positive and negative information). The registry contains solely negative information in one country only. There are important variations in (i) coverage, with some public credit registries including information from leasing or factoring companies for example, while others do not; (ii) access to the information, which is restricted to banks in some countries, but can include insurance companies or some asset management companies in others; (iii) the duration for which data is available (which is generally around five years); and (iv) the frequency at which these databases are updated. The public credit registry is generally held by the central bank.

114. Commercial credit reporting companies which cover SMEs are widespread (with 28 countries reporting that such companies are in place). Public authorities have mainly supported the development of private credit bureaus (11 countries) and credit rating agencies (10 countries). Aggregation companies and scoring platforms are developing, with the information collected including utility bills, and processed to produce credit reports, sold to any interested party.

115. Only around half of the countries which have commercial credit reporting companies have put in place an oversight of these companies. The nature of the oversight and the authority in charge vary across countries. The oversight can be ensured by the authority in charge of data privacy, the central bank, the financial supervisor or a ministry. The reflection on the risks which may go along with the benefits such companies can provide to market players and the most efficient way of mitigating and managing them is still ongoing in many countries. A few countries have taken steps to raise awareness of the General Principles for Credit Reporting ${ }^{18}$.

116. When it comes to SME accounting practices, among the 16 countries which have taken steps to improve accounting practices among SMEs, most did so through workshops raising awareness or by providing trainings, or through the publication of guidelines. Only five countries have undertaken initiatives to raise awareness on International Financial Reporting Standards (IFRS) for SMEs and the benefits they can bring in terms of access to finance. In four out of these five countries, the measures proved effective in fostering the adoption of IFRS by SMEs (in the remaining country no evaluation was conducted). A few countries signalled that there was no need to do so because national accounting standards have largely integrated IFRS for SMEs. Some countries also highlight that there are no restrictions to SME access to finance due to accounting practices.

117. One country is developing a Business Advisory Hub aimed at further assisting SMEs to improve their accounting practices by having all relevant information in one place; this is in addition to an important offer of awareness campaigns, training, mentoring (which includes a 4-week 'small business accounting' course to give participants confidence in working their business books and records, as well as the knowledge to keep proper books of account, and to deal with all necessary obligations).

118. Another country has put in place annual accounting consultations which aim at explaining to SMEs the main requirements of accounting law and national accounting

${ }^{18}$ Please see General Principles for Credit Reporting. 
standards, i.e. how to apply accounting requirements in practice, in order to improve the quality of the financial statements. These consultations are organised in different cities and are free of charge. They complete the possibility for accountants to get advice on practical accounting issues from the Authority of Audit, Accounting, Property Valuation and Insolvency Management through consultations on the phone, by e-mail or at the office, and publicly available guidelines of national accounting standards, which provide examples of practical application and detailed explanation of accounting requirements.

119. As regards credit rating agencies, one country has promoted the healthy development of the sector by introducing industry standards, regulating the sector and strengthening guidance.

120. Incentives for SMEs to have their accounts audited are rare. In the few countries which have introduced such incentives, they appear to have proven effective in encouraging SMEs to have their accounts audited.

\section{Innovative approaches}

121. One country has adopted a credit information policy requiring designated banks to share information on their SME customers with other lenders through designated Credit Reference Agencies, so as to increase competition by making it easier for alternative lenders to make good credit assessments on SMEs, and help SMEs access finance from alternative lenders.

122. One country provides funding to an organisation of more than 11,000 senior executive volunteers that provide free advice to SMEs. This comes in addition to an online learning centre with courses available to anyone with internet access, which includes six courses dedicated to SME finance.

123. In order to encourage SMEs to have their accounts audited, one country has included audited accounts among eligibility criteria of some public programmes supporting SME access to finance.

Selected effective approaches to improve transparency in SME finance markets, based on survey results

- Digitising the business registry to make it more accessible, and also to improve the quality and comprehensiveness of the information provided, including by enabling the uploading of documents like financial statements for free.

- Putting in place a public credit registry or supporting the development of private credit bureaus.

- Improving SME accounting practices through workshops raising awareness, trainings or the publication of guidelines, including online options.

- Raising awareness about IFRS for SMEs, and the benefits they can bring in terms of access to finance. 


\section{Principle 7. Enhance SME financial skills and strategic vision}

To enable SMEs to develop a long-term strategic approach to finance and improve business prospects, public policies should champion SMEs' enhanced financial literacy; their awareness and understanding of the broad range of available financial instruments; and changes in legislation and programmes for SMEs. SME managers should be encouraged to devote due attention to finance issues, acquire skills (including digital skills) for accounting and financial and risk planning, improve communication with investors and respond to disclosure requirements Efforts should also aim to improve the quality of start-ups' business plans and SME investment projects, especially for the riskier segment of the market Programmes should be tailored to the needs and financial literacy levels of different constituencies and target groups, including groups that are underserved by financial markets, such as women, young entrepreneurs, minorities, and entrepreneurs in the informal sector, and to different stages in the SME business cycle.

124. Many countries address the needs of SMEs for improved financial literacy through coordinated strategies devoted to financial education or SMEs/entrepreneurship. Some other countries and economies are developing or implementing national strategies for financial education ${ }^{19}$, some of which have identified SMEs and entrepreneurs as intended target audiences. In a few other countries and economies initiatives to enhance the financial skills of SMEs are part of strategies to develop entrepreneurship or to foster financial inclusion. Dedicated measures to improve the financial skills of SMEs are a common feature of such strategies.

125. Public institutions leading these strategies typically engage with the private and not-for-profit sector to cooperate and coordinate their awareness and education activities. Commercial banks and financial industry associations are often mentioned as important stakeholders to enhance the financial skills of SME owners and managers, due to their close contact with firms in the lending process. Other organisations with direct access to businesses, such as chambers of commerce and sectoral business associations, are also frequently involved in the design of SME policies on financial skills and play an important role in the implementation of these strategies at the local level.

126. Measuring the financial skills of SME owners and managers in order to identify their strengths and weaknesses is not an established practice. Only four countries conducted dedicated financial literacy surveys on representative samples of

\footnotetext{
${ }^{19}$ See the 2015 OECD/INFE Policy handbook on the implementation of national strategies for financial education.
} 
SMEs with a questionnaire specifically developed to capture the financial literacy of managers/owners of SMEs (as opposed to most financial literacy surveys, which are targeted to households/consumers). More countries may engage in such an exercise once the OECD/INFE finalises a survey instrument to measure the financial literacy of micro and small business owners, expected to be released in the course of 2018.

127. Some other countries have made an attempt to gather evidence on the financial skills of SME owners and managers by including booster samples of entrepreneurs or SMEs in broader financial literacy samples of adults, or by analysing responses separately by employment status (typically looking at those who report that they are self-employed). One country collected qualitative information from representatives of government authorities involved in supporting the development of SMEs' financial skills and strategic vision.

128. When targeting SMEs, national strategies for financial education tend to focus on the foundations of financial literacy for SME owners and managers (including basic knowledge of financial concepts and understanding traditional financial products), while SME strategies put an accent on more applied and operational tools to improve access to SME financing, such as drafting good business plans and accessing/managing credit. The most common topics included in strategies and programmes aiming at providing financial skills to the smallest players (potential entrepreneurs and/or micro-enterprises), include an understanding of basic financial principles (such as risk diversification, interest compounding and the effect of inflation), an understanding of financial products, and knowledge of how to access and manage credit.

129. In developing the content of its SME financial education activities, one country has created a fully-fledged core competency framework for financial training to serve as commonly agreed basis across different stakeholders. Some other governments have also identified particular topics considered of relevance for SME owners and managers, albeit without creating a formal framework. These include topics such as corporate restructuring, with the aim of anticipating the start of restructuring processes, and good corporate governance, with the aim of improving financial management, reporting and facilitating assessment by potential investors.

130. Educational activities to facilitate SME access to diverse and alternative financing instruments are also being developed in some countries. These include (i) initiatives to raise awareness about the full spectrum of available funding products and services, including crowdfunding options, with the aim to broaden the base of SME financing; (ii) guidelines and trainings for valuing intangibles and using exchange platforms for receivables to increase knowledge and take-up of asset-based financing options; and (iii) counselling and mentoring to improve investor-readiness of start-ups to support equity financing.

131. Workshops, trainings and printed booklets are the most frequent channels to deliver financial education to SMEs, but more innovative ways such as mobile phone applications, online videos and e-learning platforms are also used in a smaller number of countries.

132. The choice of the preferred delivery method depends on the groups targeted by the specific financial education initiatives. While online resources, fairs, and roadshows are used in some countries, as appropriate, to reach a wide audience, dedicated workshops, business consulting and company-specific assistance are also used when the target group is smaller. A few countries reported that participation in trainings is a 
requirement for accessing grants or other sources of funding provided under SME/entrepreneurship strategies. In a few countries, state development banks supporting SMEs offer them advisory and counselling services on various issues including financial management.

133. The extent to which financial education is provided to SMEs for free or through paid-for channels varies greatly. In several countries, most basic services and information are free but some more tailored services are fee-based. Not-for-profits are less likely to charge for their services than the business sector, which most frequently provides paid-for training and mentoring.

134. A less widespread but interesting practice is the delivery of free guidance and mentoring, including on financial issues, from established entrepreneurs to less experienced ones.

135. One country reported holding semi-formal "town hall" meetings conducted in SME clusters with the participation of local entrepreneurs and representatives of financial institutions. The main goal of such meetings is to foster financial literacy and awareness among unbanked entrepreneurs to support their formal financial inclusion.

136. The SME sector as a whole is generally considered as the beneficiary of financial education initiatives included in national SME strategies or in national strategies for financial education. However, in some countries, not-for-profits and, less frequently, governments are devising special programmes tailored to sub-groups of companies and entrepreneurs such as young, women, or indigenous and immigrant entrepreneurs, and companies in the start-up phase. Targeted approaches include the development of customised training material, and in some cases of dedicated approaches (such as the involvement of female mentors in programmes dedicated to women).

137. One country highlighted a programme to enhance SME financial skills in which each training programme is tailored to the needs and knowledge level of the SME owners and managers involved, based on a diagnosis that is made at the beginning of the programme.

138. In some cases different initiatives covering specific content areas of financial education are made available to different groups of entrepreneurs based on their experience and company size.

139. Rigorous evidence on the effectiveness of financial education programmes for SMEs remains limited. Some governments and not-for-profit organisations have evaluated the effectiveness of financial education initiatives for SMEs, showing examples of positive impact of financial education interventions on indicators of business performance, such as new venture survival, access to credit, sales, and profits. And some countries have undertaken basic studies to better understand the process, reach, and participant satisfaction of programmes to enhance SME financial skills. However, rigorous impact evaluations are still far from common and empirical evidence on the effectiveness of financial education and business training programmes therefore remains limited. 
Selected effective approaches to enhance SME financial skills and strategic vision, based on survey results

- Engaging with the private and not-for-profit sector to cooperate and coordinate awareness and educational activities.

- Developing educational activities facilitating SME access to diverse and alternative financing instruments.

- Providing guidance and mentoring on financial issues from established entrepreneurs to less experienced ones.

- Tailoring each training programme to the needs and knowledge level of the SME owners and managers involved, based on a diagnosis made at the beginning of the programme. 


\section{Principle 8. Adopt principles of risk sharing for publicly supported SME finance instruments}

Public programmes for SME finance should help catalyse and leverage the provision of private resources, especially in risk capital markets. Under certain conditions, public schemes can be effective in kick-starting the offer of financing tools for SMEs. Nevertheless, leveraging private resources and competencies may be essential to enhance the resilience of SME financing in the face of rapid economic and regulatory change. Policies should aim at encouraging the participation of private investors and developing appropriate risk-sharing and mitigating mechanisms with private partners which ensure proper functioning of public measures, including the allocation of government resources to their most efficient use. Policies should also be designed to avoid "moral hazard", i.e. excessive risk-taking against the public interest, and potential crowding-out effects. Multilateral development banks (MDBs), national development banks (NDBs) and other public funds should be encouraged to promote SME financing, directly and indirectly.

\section{Common and other approaches}

140. Almost all countries have a public financial institution in operation, which is considered an effective mechanism to contribute to national objectives regarding SME access to finance (32 out of 38).

141. Two-thirds contribute to broadening the range of financing instruments available to SMEs. The non-bank instruments supported, either directly or indirectly, mentioned by participating countries are venture capital (11 countries), equity (10 countries), angel funding (five countries) and seed financing (three countries).

142. The sub-segments most targeted by the public financial institutions are startups (16 countries), women entrepreneurs (11 countries) and SMEs located in remote areas (11 countries). Other sub-segments mentioned include growth-oriented SMEs (nine countries), innovative SMEs (seven countries), SMEs expanding internationally (seven countries), high-tech start-ups (six countries), young entrepreneurs (six countries), migrants businesses (three countries), SMEs operating in the agricultural sector (two countries) and SMEs operating in the green sector (one country).

143. Practically all public financial institutions operate alongside or through private-sector players (29 out of 32). As regards the type of partner the public financial institution works with, 26 countries mention banks, 13 mention funds and 10 mention non-bank financial institutions (NBFIs). Therefore, banks largely remain the most important partner of public authorities in their policies to increase SME access to finance, with other financial institutions playing a role which is still (far) less prominent. That may somewhat constrain public financial institutions' capacity to contribute to broadening the range of financial instruments SMEs have access to. 
144. Guarantees to financing operations undertaken by SMEs with private-sector financial institutions are the most widespread type of collaboration between privatesector financial institutions and public financial institutions (the public financial institution provides guarantees in twenty-six countries). Co-investment is mentioned by slightly more than a third of countries which have a public financial institution, and a few countries offer risk-sharing instruments other than guarantees (generally first-loss risk cover up to a ceiling).

145. Direct or indirect support to increased access to finance is accompanied by technical assistance in a bit more than half of the countries which have a public financial institution contributing to increasing SME access to finance. Technical assistance is provided mainly in the fields of business management and development (nine countries) and accounting and finance (eight countries). Other areas mentioned include sales and marketing (four countries), international expansion (two countries), corporate governance (two countries), IT (two countries) and HR (two countries). Therefore, in some countries, public support to SME access to finance appears to be focused on the supply side, and less so on the demand side by providing SMEs with the knowledge and skills needed to apply for the most suitable financing instrument in a successful and sustainable manner.

146. Importantly, there appears to be scope to strengthen the evaluation of the contribution of the public financial institution to national objectives regarding SME access to finance. Fourteen out of 32 countries indicate that an evaluation was conducted. One country declares that an evaluation was conducted but not recently. And another country declares that an evaluation is currently being undertaken. Among these 14 countries, a number of countries appear to rely on measures of effectiveness which may benefit from being further developed (disbursements, increase in overall SME lending or number of loans for instance).

\section{Innovative approaches}

147. As regards evaluation, in one country the activities of the public investment fund are evaluated every three years, with the latest evaluation conducted by a consulting company, and the fund has engaged in collaboration with consultants and a business school with the aim of mapping the effects of its activities. The entire evaluation is made available online.

Selected effective approaches to adopt principles of risk sharing for publicly supported SME finance instruments, based on survey results

- Accompanying the direct or indirect provision of funding by the public financial institution with measures addressing demand-side challenges and obstacles, for example by providing SMEs with the knowledge and skills needed to apply for the most suitable financing instrument in a successful and sustainable manner.

- Conducting regular evaluations of the contribution of PFI programmes to improving and diversifying SME access to finance.

- Publishing evaluations of the activity of the public financial institution, online for instance. 


\section{Principle 9. Encourage timely payments in commercial transactions and public procurement}

Timely payments in Business to Business (B2B) and Government to Business (G2B) transactions could be encouraged to enhance the cash flow of small business suppliers. Policy makers and regulators should ensure that SMEs, which are particularly vulnerable to late payments or non-payment, are offered clear and appropriate payment terms. Norms could be designed, implemented and enforced to discourage late payments in commercial transactions, including for cross-border trade.

\section{Common and other approaches}

148. The majority of governments do not restrict the contractual freedom to pay invoices. Only around a third of surveyed countries took action in that direction to address payment delays. More (15) have put in place measures to ensure automatic entitlement to compensation for late payments. This compensation can consist of a penalty, the payment of interest or both. A number of EU countries mention that they took related measures when transposing the Late Payment Directive 2011/7/EU.

149. In one country, although no action was taken to restrict the contractual freedom to pay invoices, the public authorities encourage businesses to sign up to the national supplier code developed by the industry, which commits signatories to paying small businesses within thirty days. Similarly, another country, which has taken action to restrict the contractual freedom to pay invoices, has also introduced a Prompt Payments Code whereby signatories commit to pay suppliers on time, provide clarity in their terms and encourage good practice. A third country, which has also taken action to restrict the contractual freedom to pay invoices, has accompanied such action with two voluntary initiatives to support prompt payments: a 15-day prompt payment agreement for public sector bodies only and a voluntary prompt payment code of conduct. To date, the country counts 138 public sector and 73 private sector signatories to the code. It also launched a public campaign to advertise the code and encourage sign up, while officials attend and manage various late payment information events every year.

150. Fifteen countries have put in place mechanisms enabling SMEs to challenge unfair contractual terms and practices. Only one of them has conducted a study on the use of such mechanisms by SMEs, and specifies that a survey is conducted every year. Other countries do not assess the effectiveness of these measures.

151. Governments appear to focus their effort on payments by public bodies, with 21 countries which have implemented measures to ensure automatic entitlement to compensation for late payments by a public body. Eight specify that late payment by a public body results in a right for SMEs to claim interest (upon meeting certain conditions in one country), and two that SMEs are entitled to the payment of both a penalty and interest. 
152. While 25 out of 38 countries did not provide an answer to that question, five countries report that measures to ensure automatic entitlement to compensation for late payments by a public body or mechanisms enabling SMEs to report late payments by a public body resulted in an improvement in the delays under which public bodies settle their bills and can provide supportive evidence (three other countries report an improvement but without supportive evidence and five countries declare that no improvement was observed, yet). Among these five countries, one country reports that the average payment time of public orders has decreased from 45.1 days in 2011 to 24.5 in 2016. Another one reports that the average payment delay decreased by more than $48 \%$ in 2016 compared to the previous year.

\section{Innovative approaches}

153. One country has established an Observatory of payment delays, which gathers a number of Directorates from Ministries and representatives from the Statistics Office, and examines the conditions of payments between enterprises every year, based on data on companies' balance sheets provided by the central bank. This Observatory has proven quite effective in contributing to the reduction of payment delays.

154. Among mechanisms to challenge unfair contractual terms and practices, in one country the Mediator of Enterprises is competent on all questions related to payment delays, whether the client is public or private. The Mediator of Enterprises has proven to be an effective mechanism to support SMEs when faced with unfair contractual terms and practices and the non-respect of payment terms is one of the main reasons for resorting to the Mediator, with 1,200 cases in 2017. Likewise, another country has launched a complaint handling service of its Small Business Commissioner, to ensure fair payment practices for small businesses. The Small Business Commissioner advises on SME complaints and challenges on late payment and payment terms, including considering complaints and providing an alternative dispute resolution service.

155. Nine countries have put in place mechanisms enabling SMEs to report late payments by a public body. Among these countries, one has designed a comprehensive programme called Timely Payment, which aims at promoting supplier payment by public institutions in thirty days or less. The programme is structured around five dimensions: (i) timely information: the programme provides public institutions officials permanent information related to their institution's payment behaviour; (ii) an application through which both suppliers and public institutions can manage their payment process; (iii) claim management: a unit follows up on payment claims made by suppliers; (iv) training: the programme trains both suppliers and public institutions on payment procedures and good payment practices; (v) strategic alliances: the programme signed strategic alliances with specific actors, mostly public institutions. These countries gather statistics regarding the use of such entitlement or mechanisms.

156. In one country the government surveys and reports on the payment performance of its agencies with the Pay On Time Survey, which also reports on the amount of penalty interest paid across reporting agencies. In another one, as part of the Management Accountability Framework process, departments are required to provide, on an annual basis, for the latest completed fiscal year, the following elements: the number of payments to suppliers made on time, the total number of payments to suppliers, and the percentage of payments to suppliers made on time. Going beyond, one country has put in place a system which records all the information reported in electronic invoices. This system allows gathering the number of invoices issued by each supplier and their amount, 
as well as the number of invoices received by each public body and their amount. It reports payment times and possible delays and allows to calculate the average payment period and delay for each public body. In one country, all information on payment performance by public bodies is available online, ensuring a high level of accountability and transparency. Another interesting example is a Government Payment Service Monitor under which the Ministry reports to Parliament on the payment behaviour of public bodies. The monitor includes central government and local authorities, and is also published online.

157. Finally, one country has put in place project bank accounts in some sectors, to ensure prompt payment by public bodies to the supply chain. A project bank account is a bank account with trust status used to make payments to suppliers working on a project, whilst providing protection to beneficiaries in case of insolvency.

Selected effective approaches to encourage timely payments in commercial transactions and public procurement, based on survey results

- - Tracking delays in payments by public bodies, consolidating related data, and potentially also publishing it (online) or sharing it with the Parliament.

- - Putting in place mechanisms enabling SMEs to report late payments by public bodies.

- - Establishing an Observatory of payment delays to examine the conditions of payments between enterprises.

- - Creating a Mediator or Commissioner competent on all questions related to payment delays, whether the client is public or private.

- - Setting up project bank accounts to ensure public bodies prompt payments to suppliers working on a project. 


\section{Principle 10. Design public programmes for SME finance which ensure additionality, cost effectiveness and user-friendliness}

The design of public programmes to enhance SME access to finance should ensure financial and economic additionality, along with cost effectiveness. Policy coherence across levels of government and between government and non-government bodies dealing with SME finance should be pursued, based on reliable evidence. The target population, eligibility criteria, credit risk management and fees structure should be considered carefully and defined clearly when designing programmes, which should be easy to understand for SMEs. The administrative burden and compliance costs of new and existing policies should be proportionate to the service provided, the impact on beneficiary firms and the broader economy, as well as to the nature and size of the targeted businesses.

\section{Common and other approaches}

158. Almost all countries declare ensuring financial additionality when designing and implementing public programmes for SME finance (32 out of 38), and many (25) declare that a framework is in place to ensure that programmes for SME finance generate economic additionality. On the other hand, there appear to be wide differences in what the concept of additionality covers across countries, particularly economic additionality (while the definition of financial additionality seems more consistent and capturing the need for public programmes not to crowd out the private sector and rather address a financing gap). In addition, most of the time, the information provided as regards how additionality is assessed, whether financial or economic, suggests that there is scope for methodological improvements in that area.

159. Twenty-five countries report that a framework is in place to ensure that the costs associated with the implementation of public programmes do not outweigh their benefits. On the other hand, less than a third of surveyed countries report conducting a formal assessment. For countries which do conduct an assessment, ex post assessment is the most widespread (12 countries), with ex ante assessment coming next (nine countries), and with few countries monitoring this along the transaction. Additionally, assessments rely on clearly defined and measurable key performance indicators - KPIs in just two countries.

160. Twenty-eight countries have put in place coordination mechanisms to ensure the consistency of policies aiming to enhance SME access to finance across levels of government, while twenty-four have put in place coordination mechanisms to ensure the consistency of policies between government and non-government bodies.

161. Responses suggest that governments recognise the importance of raising SMEs' awareness to programmes for which they may be eligible. Indeed, 31 countries ensure that SMEs are made aware of public SME finance programmes in a transparent and clear 
manner, through dedicated websites (nine countries), awareness campaigns (three countries) or both (14 countries).

162. In one country, the Business Network is the government's multi-channel information and advisory service for small businesses and entrepreneurs. It provides information and advice to SMEs that are seeking government programmes, services, permits, licenses and regulations to start, manage, finance and grow a business. Its main service delivery channels include a website of programmes and services, toll-free telephone and email services, as well as in-person services provided through local service centres. Additionally, each local service centre is mandated to undertake outreach and information sessions in their particular geographic region. Through these initiatives, centre staff gives presentations, attend conferences, and offer training sessions to help inform local SMEs about programmes and services that are available to them, including SME financing programmes.

163. Numerous countries have also taken steps to facilitate access to SME financing programmes, mainly by making relevant information available online. In some cases, the application process can also be completed online.

\section{Innovative approaches}

164. Requiring some form of evidence of additionality in the form of refusals from financial institutions is an approach that appears to be effective. In one country rejection letters from two financial institutions are necessary to be eligible to a guarantee, so as to ensure that the borrower would not qualify for a loan from a private-sector financial institution on reasonable terms without a government guarantee. In another country, lenders must first apply their normal lending requirement to assess a borrower's finance application, and only applications that are unsuccessful are then offered a loan under the programme, against payment of a two percent annual guarantee fee to the government.

165. As regards SME awareness of government programmes to support SME finance, one country has put in place an SME Online Tool thanks to which, by answering eight simple questions, a business owner or entrepreneur can find out which support programmes are available to them.

Selected effective approaches to design public programmes for SME finance which ensure additionality, cost effectiveness and user-friendliness, based on survey results

- Defining a clear methodology to assess the additionality of contemplated measures to increase SME access to finance, and putting in place procedures to make sure that this assessment is done in a systematic manner.

- Requiring evidence of additionality, in the form of refusals from financial institutions for instance.

- Raising SME awareness of public programmes for SME finance for which they may be eligible through dedicated websites coupled with awareness campaigns in various locations, and partnering with business associations or local authorities to increase outreach. 


\section{Principle 11. Monitor and evaluate public programmes to enhance SME} finance

Monitoring and evaluation of policies to ease SMEs' access to finance should be promoted. Ex ante and ex post evaluation should be performed regularly based on clearly defined, rigorous and measurable policy objectives and impacts and in co-operation with financial institutions, SME representatives and other stakeholders. Evaluation findings should feed back into the process of policy making, in particular when measures fail to meet their stated objectives or are found to have undesirable impacts. Regional, national and international policy dialogue and exchange of experiences on how to monitor and evaluate public programmes to enhance SME finance should be encouraged.

\section{Common and other approaches}

166. Responses suggest a significant contrast between governments' recognition of the importance of evaluating programmes to increase SME access to finance on the one hand, and the degree to which corresponding evaluation methodologies and procedures are in place on the other hand.

167. Almost all countries have a framework in place to ensure the evaluation of SME finance programmes ( 35 out of 38 , and one is establishing it). This framework includes an ex ante evaluation in 29 countries, continuous monitoring in 32 countries, and an ex post evaluation in 33 countries. On the other hand, these evaluations and monitoring are not always systematic, and may be conducted only on a case-by-case basis.

168. When asked whether mechanisms are in place to ensure that monitoring and evaluation needs are taken into account at the design stage of the programmes, while 32 countries declare that such mechanisms are in place, only 22 can provide examples of such mechanisms. Likewise, while 29 countries report that evaluations are based on clearly defined, rigorous and measurable policy objectives and impacts, although not always in a systematic manner, the examples provided only sometimes meet these criteria. In particular, objectives and impacts seem to be rarely quantified, and their achievement even more rarely assessed against baselines set at the beginning of the implementation phase.

169. One country conducts "incrementality studies", which seek to determine the extent to which the programme has assisted SMEs in accessing financing that they would not otherwise have been able to access in the absence of the programme (i.e. their additionality). Another country conducted a study of both the guarantee fund's additionality and its contribution to the economy relative to its cost. Finally, one country mentions research articles which have looked into the incremental lending to SMEs which resulted from the programmes implemented by the country to directly support SME lending. 
170. Most countries engage a series of stakeholders in the evaluation process, including beneficiaries and partner financial institutions, generally through surveys, interviews, focus groups or a combination of these, which appear to be effective ways of gathering feedback and views on public programmes. One country, when reviewing one of its guarantee programmes, received input from over 50 stakeholders including individual businesses and business representatives, representatives from the accountancy and advisory professions, representatives from banks, responsible finance providers, asset-based lenders and academics. In addition, as part of the review, an independent study was conducted by a consultancy to undertake a qualitative assessment with delivery partners and borrowers to assess the effectiveness of the scheme and identify potential delivery barriers. This research involved conducting in-depth interviews and focus groups with fifteen lenders and in-depth interviews with twenty-four borrowers. The borrower interviews were structured by the type of lender from which they had accessed their supported loan.

171. Although they are not systematic, and may benefit from relying on more rigorous methodologies and metrics, evaluations are published in 28 countries, and available online in 18 out of these 28 countries.

172. It is unclear whether the general public has any knowledge of the availability of evaluation reports. Very few countries communicate about their findings. The ones which do so generally conduct press conferences. There are also a few examples of seminars during which the findings are shared and thought through by various stakeholders (public bodies, beneficiaries, financial institutions, academics, etc.), to draw the lessons of the evaluations, so that they feed into upcoming programmes.

173. Accountability seems to be to the Parliament. Indeed, in numerous countries, the results of evaluations are sent to the Parliament or a specific Parliament committee, or discussed in a dedicated session (with the former prevailing over dedicated sessions and discussions). These processes are sometimes linked to the budget process, with the provision of more funding or the continuation of funding of the programme dependent on positive evaluation results.

174. There appears to be scope to strengthen the extent to which the findings of evaluations are taken into account in designing new programmes. While a large majority of countries seem to view this as a logical and important step, very few countries have put in place procedures and processes ensuring that this is the case. Most countries mention only sharing evaluation reports, while this in itself does not guarantee that the findings of evaluation reports are taken into account.

175. In order to encourage the exchange of experiences on how to monitor and evaluate SME finance public programmes one country holds a periodical international evaluation conference co-organised by the Ministry of Economic Development and the Agency for Enterprise Development. In another country, the Agency for Growth Policy Analysis was requested by the government to arrange a series of seminars for the Government Offices and various agencies tasked with implementing growth policy, with the objective of spreading and sharing knowledge about how to monitor and evaluate growth policy programmes in general, including SME finance programmes. Finally, one country has an evaluation network which serves as a forum for the exchange of experience and information among evaluators, clients and users. 


\section{Innovative approaches}

176. In one country, the evaluations of the National Council of Evaluation of Social Development Policies take into consideration a Matrix of Indicators for Results for the analysis of the programmes of the National Entrepreneur Fund. These include evaluation of design, performance and consistency in results using the logframe methodology. These evaluations are programmed in the Annual Evaluation Program. The objective is to analyse the impact of the support offered, in order to allocate resources more efficiently, and focus them on the activities which meet objectives.

Selected effective approaches to monitor and evaluate public programmes to enhance SME finance, based on survey results

- Setting clear objectives for public programmes in SME finance, and defining performance indicators capturing these objectives, preferably including quantitative indicators, to be assessed against baselines set at the beginning of the programme, both along the programme (continuous/regular monitoring), and at its completion (ex post evaluation).

- Conducting systematic evaluations of public programmes, based on explicit and clear methodologies.

- Engaging all relevant stakeholders (including beneficiaries and partner financial institutions, etc.) in the evaluation process, for instance through surveys, interviews, focus groups, or a combination of these.

- Sharing evaluations with the Parliament, and discussing them during dedicated sessions of the relevant parliamentary group.

- Making the continuation of the programme, or the provision of new funding, conditional to the submission of an evaluation report showing that it has been successful, including by linking the budget process and the evaluation process.

- Putting in place clear procedures ensuring that the findings of evaluations are taken into account when designing new programmes.

- Publishing evaluations and raising public awareness on their availability 


\section{Annex A. SUMMARY TABLE OF COMMON AND OTHER, INNOVATIVE AND EFFECTIVE APPROACHES}

\begin{tabular}{|c|c|}
\hline \multirow{3}{*}{$\begin{array}{l}\text { Assessing the extent to which SMEs' financing needs are } \\
\text { met and where gaps exist. }\end{array}$} & $\begin{array}{l}\text { Common and other approaches } \\
\text { - Collecting data on bank loans through the central bank or the statistics office, through } \\
\text { reportings or surveys, with breakdowns by size, sector and location. } \\
\text { - Collecting data on SME loan stocks, interest rates and NPLs. } \\
\text { - Relying on the data collected by relevant business associations for data on PE and } \\
\text { VC investments in SMEs. } \\
\text { - Collecting data on SMEs which do not have access to mainstream financial products } \\
\text { and services through surveys conducted by public bodies, with breakdowns by sector } \\
\text { and size. } \\
\text { - Publishing the assessment of SME financing needs online. }\end{array}$ \\
\hline & $\begin{array}{l}\text { Innovative approaches } \\
\text { - Partnership between public bodies (central bank, ministry of finance and/or statistics } \\
\text { office) and private equity, venture capital or angel capital business associations, to } \\
\text { conduct surveys on the state of SME financing in these segments. }\end{array}$ \\
\hline & $\begin{array}{l}\text { Effective approaches } \\
\text { - Collecting quantitative data on SME finance through reporting to, and surveys } \\
\text { conducted by, public bodies (central bank, statistics office, etc.). } \\
\text { - Collecting data on funds received by SMEs from private equity and venture capital } \\
\text { firms, or business angels, through the relevant business associations. } \\
\text { - Partnership between public bodies (central bank, ministry of finance and/or statistics } \\
\text { office) and private equity, venture capital or angel capital business associations, to } \\
\text { conduct surveys on the state of SME financing in these segments. } \\
\text { - Gathering comparative evidence from other countries and regions through the OECD } \\
\text { Scoreboard on Financing SMEs and Entrepreneurs. }\end{array}$ \\
\hline \multirow{2}{*}{$\begin{array}{l}\text { Cooperating with relevant stakeholders, including central } \\
\text { banks and financial supervisory authorities, financial and } \\
\text { research institutions and SME representatives. }\end{array}$} & $\begin{array}{l}\text { Common and other approaches } \\
\text { - Involving relevant stakeholders through an SME committee or panel, or through ad } \\
\text { hoc consultations. }\end{array}$ \\
\hline & $\begin{array}{l}\text { Effective approaches } \\
\text { - Involving relevant stakeholders in the assessment of SME financing gaps through an } \\
\text { institutionalised SME committee or panel, or through ad hoc consultations. }\end{array}$ \\
\hline \multirow{2}{*}{$\begin{array}{l}\text { Cooperating at the national and international levels to } \\
\text { increase transparency regarding definitions and improve the } \\
\text { comparability of data and indicators, facilitate international } \\
\text { benchmarking, and regulatory coordination, and shed light } \\
\text { on outstanding financing gaps and issues. }\end{array}$} & $\begin{array}{l}\text { Common and other approaches } \\
\text { - Contributing to international efforts to improve the comparability of statistical data on } \\
\text { SME finance. }\end{array}$ \\
\hline & $\begin{array}{l}\text { Effective approaches } \\
\text { - Gathering comparative evidence from other countries and regions through the OECD } \\
\text { Scoreboard on Financing SMEs and Entrepreneurs. } \\
\text { - Publishing the government assessment of SME financing needs and trends online. }\end{array}$ \\
\hline \multicolumn{2}{|c|}{ Principle 2. Strengthen SME access to traditional bank financing. } \\
\hline $\begin{array}{l}\text { Improving banks' capacity to lend to SMEs, including } \\
\text { through credit guarantees, securitisation, credit insurance } \\
\text { and adequate provisioning for loan losses. }\end{array}$ & $\begin{array}{l}\text { Common and other approaches } \\
\text { - Providing guarantees to SME loans. } \\
\text { - Targeting specific sub-segments in guarantee programmes, in particular innovative }\end{array}$ \\
\hline
\end{tabular}




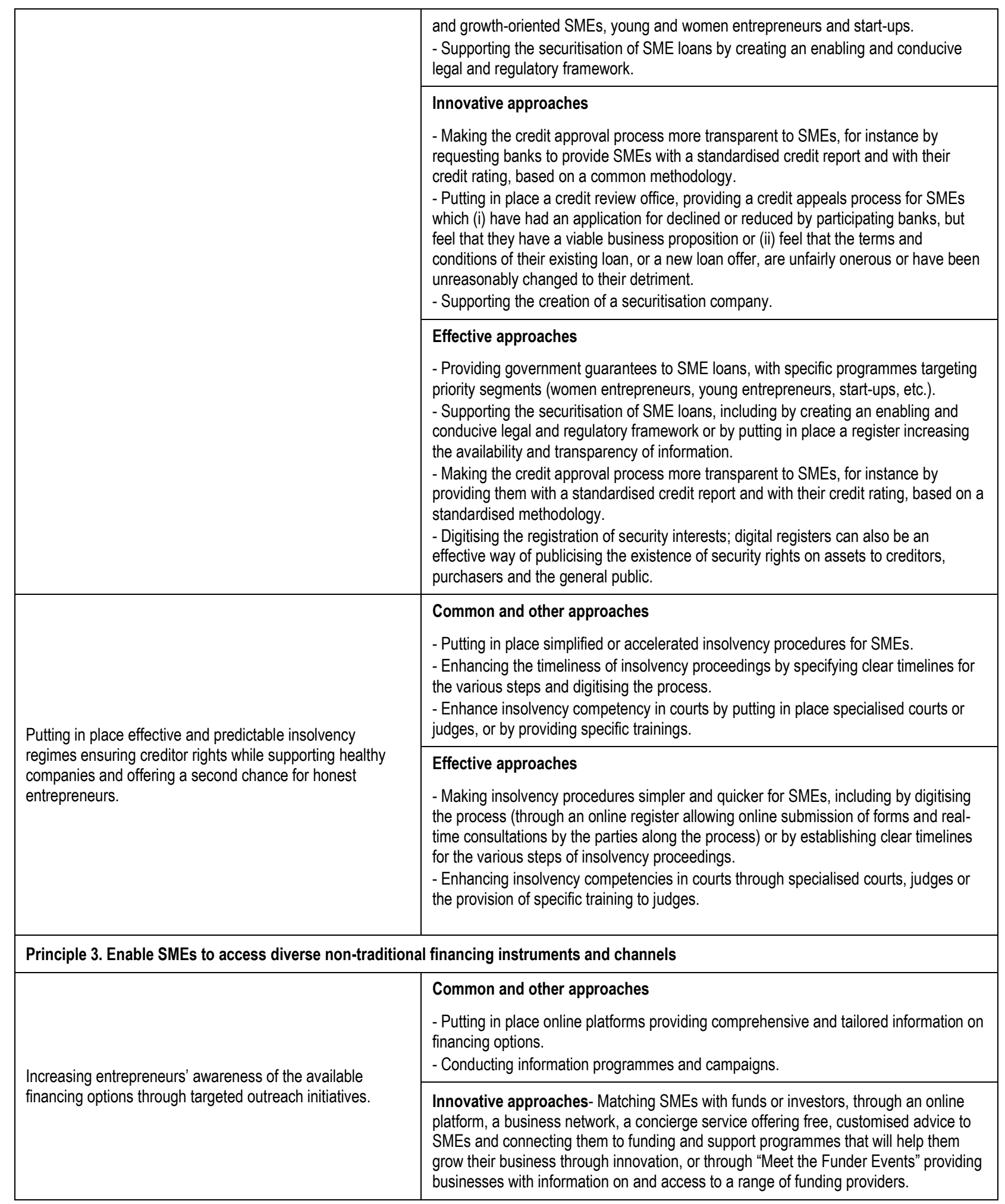




\begin{tabular}{|l|l|}
\hline & Effective approaches \\
& - Increasing awareness of SME owners and managers of all available financing options \\
through a combination of online platforms, information programmes and seminars, & delivered in various locations across the country. \\
& - Matching SMEs with funds or investors through an online platform or through \\
dedicated events. & - Improving the investor-readiness of start-ups and SMEs through accelerators or \\
incubators providing them with training as well as mentoring, coaching and networking & \\
& opportunities. \\
& - Putting in place a referral regime whereby SMEs rejected for credit by the largest \\
banks must be offered a referral to a designated, online finance platform.
\end{tabular}




\begin{tabular}{|c|c|}
\hline Broadening the base of SME investors. & $\begin{array}{l}\text { Common and other approaches } \\
\text { - Establishing tax incentives encouraging retail investors to invest in SME financial } \\
\text { markets. }\end{array}$ \\
\hline $\begin{array}{l}\text { Fostering alternative forms of debt: corporate bonds and } \\
\text { private placements. }\end{array}$ & $\begin{array}{l}\text { Common and other approaches } \\
\text { - Introducing measures to enhance the public issuance, trading and clearing conditions } \\
\text { of corporate debt securities. }\end{array}$ \\
\hline \multirow{2}{*}{$\begin{array}{l}\text { Strengthening SMEs' capital structure and boosting } \\
\text { investment in innovative start-ups and high-growth SMEs. }\end{array}$} & $\begin{array}{l}\text { Common and other approaches } \\
\text { - Making direct equity investments in SMEs through a government or government- } \\
\text { related institution, generally co-investments alongside private-sector players. } \\
\text { - Putting in place a clear regulatory framework for equity crowdfunding. }\end{array}$ \\
\hline & $\begin{array}{l}\text { Innovative approaches } \\
\text { - Supporting SMEs which are or will be listed, in the form of mentoring/coaching, with } \\
\text { the objective of helping them comply with listing requirements. } \\
\text { - Establishing tax incentives to support equity investments in SMEs. } \\
\text { - Adapting listings' rules and requirements to small equity issuers. }\end{array}$ \\
\hline \multicolumn{2}{|c|}{ Principle 4 - Promote financial inclusion for SMEs and ease access to formal financial services, including for informal firms } \\
\hline \multirow{3}{*}{$\begin{array}{l}\text { Maximising the number of SMEs which have access to and } \\
\text { use mainstream financial services and products at a } \\
\text { reasonable cost. }\end{array}$} & $\begin{array}{l}\text { Common and other approaches } \\
\text { - Targeting young entrepreneurs, SMEs located in remote areas and women } \\
\text { entrepreneurs as priority segments. } \\
\text { - Providing access to a guarantee, subsidies and various exemptions. } \\
\text { - Providing public support to MFIs. } \\
\text { - Supporting the development of Fintech solutions by creating an enabling and } \\
\text { conducive legal and regulatory framework. }\end{array}$ \\
\hline & $\begin{array}{l}\text { Innovative approaches } \\
\text { - Structuring programmes specifically designed for a targeted sub-segment, based on } \\
\text { a thorough assessment to identify the specific challenges the segment faces. } \\
\text { - Providing MFIs with the credit reports of the credit bureau at a lower price, in } \\
\text { exchange for reporting data on their customers to the credit bureau. } \\
\text { - Conducting an econometric evaluation using propensity matching to assess } \\
\text { government support to MFIs, and see whether the program has reached the target } \\
\text { group and succeeded in helping them. } \\
\text { - Putting in place regulatory sandboxes to support the development of Fintech } \\
\text { solutions. } \\
\text { - Partnering with the private sector to develop an early payment and supply chain } \\
\text { finance solution to strengthen SME access to liquidity. } \\
\text { - Supporting the creation of an association of Fintech companies in the country. }\end{array}$ \\
\hline & $\begin{array}{l}\text { Effective approaches } \\
\text { - Including relevant breakdowns (by gender, by location, etc.) in the collection of data } \\
\text { on SMEs which do not have access to mainstream financial services and products, so } \\
\text { as to design evidence-based policies targeting priority segments. } \\
\text { - Developing specific programmes for priority segments, based on a thorough } \\
\text { assessment of the specific challenges and obstacles they face. }\end{array}$ \\
\hline \multicolumn{2}{|c|}{$\begin{array}{l}\text { Principle 5. Design regulation that supports a range of financing instruments for SMEs, while ensuring financial stability and investor } \\
\text { protection }\end{array}$} \\
\hline $\begin{array}{l}\text { Ensuring that regulation is designed and implemented that } \\
\text { facilitates SMEs' access to a broad range of financing } \\
\text { instruments. }\end{array}$ & $\begin{array}{l}\text { Common and other approaches } \\
\text { - Conducting a review of the legal and regulatory framework to identify measures } \\
\text { restricting SME access to finance. } \\
\text { - Considering the potential impact of relevant upcoming laws and regulations at the } \\
\text { drafting stage. }\end{array}$ \\
\hline
\end{tabular}




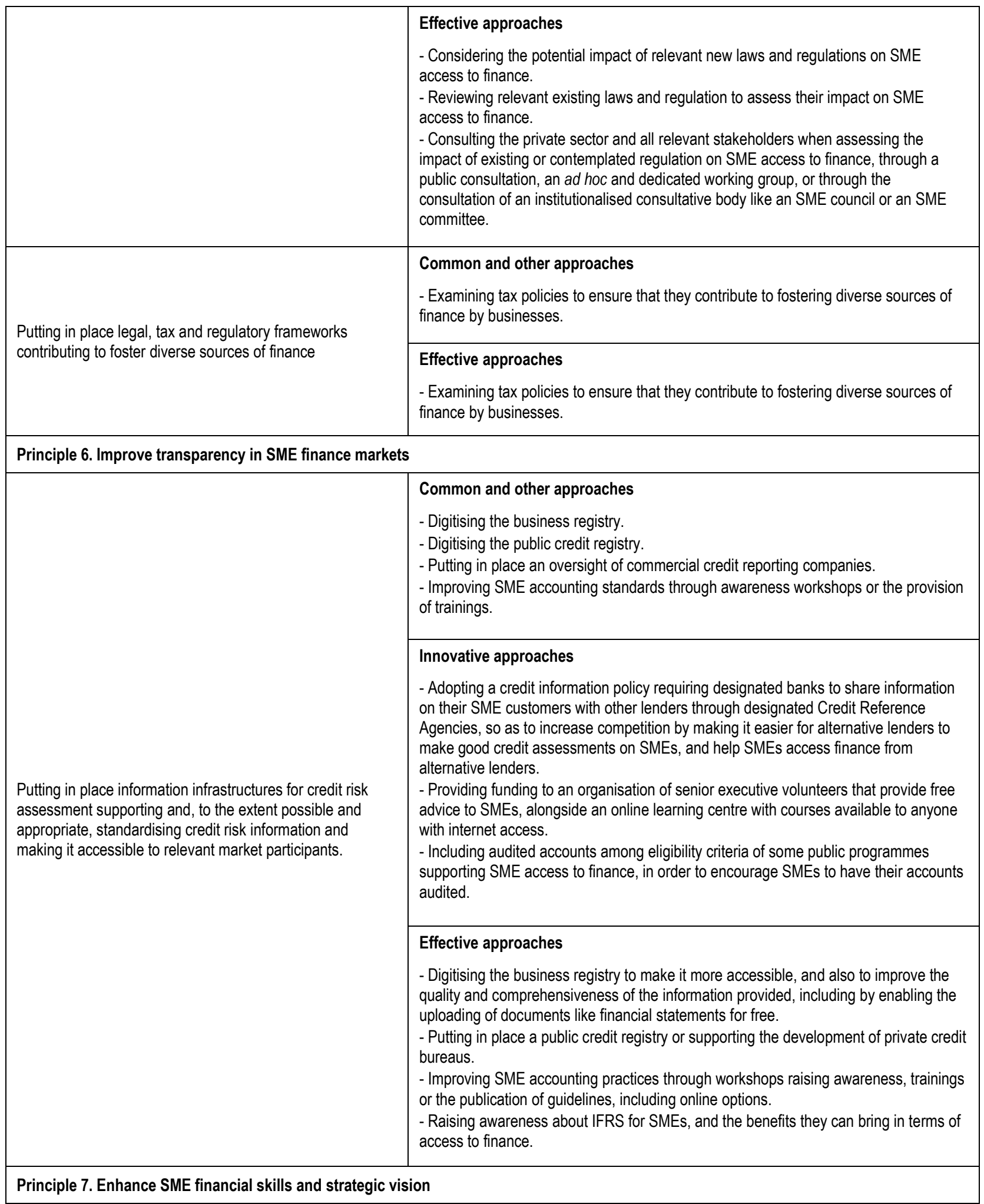




\begin{tabular}{|c|c|}
\hline \multirow[b]{2}{*}{$\begin{array}{l}\text { Championing SMEs' enhanced financial literacy; their } \\
\text { awareness and understanding of the broad range of } \\
\text { available financial instruments. }\end{array}$} & $\begin{array}{l}\text { Common and other approaches } \\
\text { - Engaging with the private and not-for-profit sector to cooperate and coordinate } \\
\text { awareness and educational activities. } \\
\text { - Delivering financial education to SMEs through workshops, trainings and booklets. }\end{array}$ \\
\hline & $\begin{array}{l}\text { Effective approaches } \\
\text { - Engaging with the private and not-for-profit sector to cooperate and coordinate } \\
\text { awareness and educational activities. } \\
\text { - Developing educational activities facilitating SME access to diverse and alternative } \\
\text { financing instruments. } \\
\text { - Providing guidance and mentoring on financial issues from established entrepreneurs } \\
\text { to less experienced ones. }\end{array}$ \\
\hline $\begin{array}{l}\text { Tailoring programmes to the needs and financial literacy } \\
\text { levels of different constituencies and target groups. }\end{array}$ & $\begin{array}{l}\text { Effective approaches } \\
\text { - Tailoring each training programme to the needs and knowledge level of the SME } \\
\text { owners and managers involved, based on a diagnosis made at the beginning of the } \\
\text { programme. }\end{array}$ \\
\hline \multicolumn{2}{|c|}{ Principle 8. Adopt principles of risk sharing for publicly supported SME finance instruments } \\
\hline \multirow{3}{*}{ Promoting SME financing, directly and indirectly. } & $\begin{array}{l}\text { Common and other approaches } \\
\text { - Having a public financial institution (PFI) contributing to national objectives regarding } \\
\text { SME access to finance. } \\
\text { - The PFI operates alongside private players, mainly banks. } \\
\text { - Accompanying direct and indirect support with technical assistance. }\end{array}$ \\
\hline & $\begin{array}{l}\text { Innovative approaches } \\
\text { - Evaluating the activities of the public investment fund every three years, with the } \\
\text { latest evaluation conducted by a consulting company, and engaging in collaboration } \\
\text { with consultants and a business school with the aim of mapping the effects of its } \\
\text { activities. }\end{array}$ \\
\hline & $\begin{array}{l}\text { Effective approaches } \\
\text { - Accompanying the direct or indirect provision of funding by the public financial } \\
\text { institution with measures addressing demand-side challenges and obstacles, for } \\
\text { example by providing SMEs with the knowledge and skills needed to apply for the } \\
\text { most suitable financing instrument in a successful and sustainable manner. } \\
\text { - Conducting regular evaluations of the contribution of PFI programmes to improving } \\
\text { and diversifying SME access to finance. } \\
\text { - Publishing evaluations of the activity of the public financial institution, online for } \\
\text { instance. }\end{array}$ \\
\hline \multicolumn{2}{|c|}{ Principle 9. Encourage timely payments in commercial transactions and public procurement } \\
\hline \multirow[b]{2}{*}{$\begin{array}{l}\text { Encouraging timely payments in Business to Business } \\
\text { (B2B) and Government to Business (G2B) transactions and } \\
\text { ensuring that SMEs are offered clear and appropriate } \\
\text { payment terms. }\end{array}$} & $\begin{array}{l}\text { Common and other approaches } \\
\text { - Putting in place mechanisms enabling SMEs to challenge unfair contractual terms } \\
\text { and practices. } \\
\text { - Ensuring automatic entitlement to compensation for late payments by a pubic body. }\end{array}$ \\
\hline & $\begin{array}{l}\text { Innovative approaches } \\
\text { - Establishing an Observatory of payment delays which examines the conditions of } \\
\text { payments between enterprises. } \\
\text { - Creating a Mediator of Enterprises, competent on all questions related to payment } \\
\text { delays, whether the client is public or private, to support SMEs when faced with unfair } \\
\text { contractual terms and practices. } \\
\text { - Launching a complaint handling service of the Small Business Commissioner, to } \\
\text { ensure fair payment practices for small businesses. The Small Business } \\
\text { Commissioner advises on SME complaints and challenges on late payment and } \\
\text { payment terms, including considering complaints and providing an alternative dispute } \\
\text { resolution service. }\end{array}$ \\
\hline
\end{tabular}




\begin{tabular}{|c|c|}
\hline & $\begin{array}{l}\text { - Putting in place mechanisms enabling SMEs to report late payments by a public } \\
\text { body. } \\
\text { - Conducting surveys on late payments, penalty and interest paid by public bodies. } \\
\text { - Establishing a system which records all the information reported in electronic } \\
\text { invoices. The system gathers the number of invoices issued by each supplier and their } \\
\text { amount, as well as the number of invoices received by each public body and their } \\
\text { amount. It also reports payment times and possible delays and allows to calculate the } \\
\text { average payment period and delay for each public body. } \\
\text { - Making the information on payment performance by public bodies available online. } \\
\text { - Putting in place a Government Payment Service Monitor under which the Ministry } \\
\text { reports to Parliament on the payment behaviour of public bodies. } \\
\text { - Setting up project bank accounts in some sectors, to ensure prompt payment by } \\
\text { public bodies to the supply chain. }\end{array}$ \\
\hline & $\begin{array}{l}\text { Effective approaches } \\
\text { - Tracking delays in payments by public bodies, consolidating related data, and } \\
\text { potentially also publishing (online) or sharing them with the Parliament. } \\
\text { - Putting in place mechanisms enabling SMEs to report late payments by public } \\
\text { bodies. } \\
\text { - Establishing an Observatory of payment delays to examine the conditions of } \\
\text { payments between enterprises. } \\
\text { - Creating a Mediator or Commissioner competent on all questions related to payment } \\
\text { delays, whether the client is public or private. } \\
\text { - Setting up project bank accounts to ensure public bodies prompt payments to } \\
\text { suppliers working on a project. }\end{array}$ \\
\hline \multicolumn{2}{|c|}{ Principle 10 - Design public programmes for SME finance which ensure additionality, cost effectiveness and user-friendliness } \\
\hline \multirow[b]{2}{*}{ Ensuring financial and economic additionality. } & $\begin{array}{l}\text { Innovative approaches } \\
\text { - Requiring some form of evidence of additionality in the form of refusals from financial } \\
\text { institutions. } \\
\text { - As regards SME awareness of government programmes to support SME finance, } \\
\text { putting in place an SME Online Tool thanks to which, by answering eight simple } \\
\text { questions, a business owner or entrepreneur can find out which support programmes } \\
\text { are available to them. }\end{array}$ \\
\hline & $\begin{array}{l}\text { Effective approaches } \\
\text { - Defining a clear methodology to assess the additionality of contemplated measures to } \\
\text { increase SME access to finance, and putting in place procedures to make sure that } \\
\text { this assessment is done in a systematic manner. } \\
\text { - Requiring evidence of additionality, in the form of refusals from financial institutions } \\
\text { for instance. } \\
\text { - Raising SME awareness of public programmes for SME finance for which they may } \\
\text { be eligible through dedicated websites coupled with awareness campaigns in various } \\
\text { locations, and partnering with business associations or local authorities to increase } \\
\text { outreach. }\end{array}$ \\
\hline \multicolumn{2}{|c|}{ Principle 11. Monitor and evaluate public programmes to enhance SME finance } \\
\hline \multirow{2}{*}{$\begin{array}{l}\text { Performing ex ante and ex post evaluations regularly based } \\
\text { on clearly defined, rigorous and measurable policy } \\
\text { objectives and impacts and in co-operation with financial } \\
\text { institutions, SME representatives and other stakeholders. }\end{array}$} & $\begin{array}{l}\text { Innovative approaches } \\
\text { - When assessing programmes, taking into consideration a Matrix of Indicators for } \\
\text { Results, which includes evaluation of design, performance and consistency in results } \\
\text { using the logframe methodology. }\end{array}$ \\
\hline & $\begin{array}{l}\text { Effective approaches } \\
\text { - Setting clear objectives for public programmes in SME finance, and defining } \\
\text { performance indicators capturing these objectives, preferably including quantitative } \\
\text { indicators, to be assessed against baselines set at the beginning of the programme, } \\
\text { both along the programme (continuous/regular monitoring), and at its completion (ex } \\
\text { post evaluation). }\end{array}$ \\
\hline
\end{tabular}




\begin{tabular}{|c|c|}
\hline & $\begin{array}{l}\text { - Conducting systematic evaluations of public programmes, based on explicit and clear } \\
\text { methodologies. } \\
\text { - Engaging all relevant stakeholders (including beneficiaries and partner financial } \\
\text { institutions, etc.) in the evaluation process, for instance through surveys, interviews, } \\
\text { focus groups, or a combination of these. }\end{array}$ \\
\hline $\begin{array}{l}\text { Making sure that evaluation findings feed back into the } \\
\text { process of policy making. }\end{array}$ & $\begin{array}{l}\text { Effective approaches } \\
\text { - Sharing evaluations with the Parliament, and discussing them during dedicated } \\
\text { sessions of the relevant parliamentary group. } \\
\text { - Making the continuation of the programme, or the provision of new funding, } \\
\text { conditional to the submission of an evaluation report showing that it has been } \\
\text { successful, including by linking the budget process and the evaluation process. } \\
\text { - Putting in place clear procedures ensuring that the findings of evaluations are taken } \\
\text { into account when designing new programmes. } \\
\text { - Publishing evaluations and raising public awareness on their availability. }\end{array}$ \\
\hline $\begin{array}{l}\text { Encouraging regional, national and international policy } \\
\text { dialogue and exchange of experiences on how to monitor } \\
\text { and evaluate public programmes to enhance SME finance. }\end{array}$ & $\begin{array}{l}\text { Innovative approaches } \\
\text { - Encouraging the exchange of experiences on how to monitor and evaluate SME } \\
\text { finance public programmes by holding a periodical international evaluation conference. } \\
\text { - Conducting a series of seminars for the Government Offices and various agencies, } \\
\text { with the objective of spreading and sharing knowledge about how to monitor and } \\
\text { evaluate SME finance programmes. } \\
\text { - Putting in place an evaluation network which serves as a forum for the exchange of } \\
\text { experience and information among evaluators, clients and users. }\end{array}$ \\
\hline
\end{tabular}




\title{
Annex B. G20/OECD HIGH-LEVEL PRINCIPLES ON SME FINANCING
}

\begin{abstract}
PREAMBLE
1. Small and medium-sized enterprises (SMEs) ${ }^{20}$, including micro-enterprises, are important engines of innovation, growth, job creation and social cohesion in high income and emerging economies as well as low-income developing countries (LIDCs) ${ }^{21}$. However, SMEs and entrepreneurs can only reach their full potential if they obtain the finance necessary to start, sustain and grow their business.
\end{abstract}

2. A lack of appropriate forms of finance is a long-standing hurdle for SMEs, with varying severity of financing constraints across countries. In developing countries, credit to the private sector as a share of GDP is well below the average in high-income countries, SME loans represent a smaller proportion of business credit and the lack of a well-developed financial infrastructure ${ }^{22}$ poses challenges. Financing is also a major constraint in advanced economies, where financing gaps for SMEs and entrepreneurs were exacerbated by the 2008-09 financial and economic crisis. Here, regulatory reforms ${ }^{23}$ are expected to have various impacts on the availability of credit to SMEs.

3. SMEs are typically at a disadvantage with respect to large firms when accessing finance, owing to opacity, under-collateralisation, high transaction costs and lack of financial skills. Financing needs and constraints vary widely across the business population. Firm size, age and phase of development have an important bearing on the type of financing needed and access to diverse financing sources. SMEs generally face higher interest rates, tighter borrowing terms and are more likely to be credit-rationed than large firms. Capital gaps also exist for innovative and growth-oriented firms, as well as for medium-size enterprises that seek to invest and expand. Informal SMEs in particular may be unserved or underserved by financial institutions. Furthermore, financial sources tend to dry up more rapidly for small firms than for large companies during economic downturns. The shortage of finance experienced by SMEs makes the economic and social impacts of economic crises more severe and long-lasting. While many SMEs face problems obtaining bank finance ${ }^{24}$, access to non-bank financing is

20 It should be noted that SMEs are defined differently across countries and regions, reflecting specificities in the economic, social and regulatory environment. Also, different definitions are adopted for different policy purposes, such as based on profitability for taxation purposes or on number of employees for employment legislation.

21 In high income economies, SMEs undertake the majority of private economic activity, accounting for more than $60 \%$ of employment and $50 \%$ of GDP. In emerging economies, SMEs contribute on average to more than $50 \%$ of employment and $40 \%$ of GDP. In LIDCs, SMEs contribute significantly to broadening employment opportunities, social inclusion and poverty reduction.

22 Financial infrastructure refers to the framework and institutions for financial sector transactions, and includes elements such as payment systems, credit information bureaus and collateral registries.

23 Such reforms may take place at the national level or the international level, for example in the case of the Basel framework.

24 Banks are here defined as licensed financial institutions, including chartered banks and credit unions, whose primary role is to receive monetary deposits from individuals and organizations, and to supply credit and other financial services to households and businesses. 
often even more constrained. Most sources of finance beyond straight bank debt ${ }^{25}$ are at the reach of only a small share of SMEs, especially in economies where private capital markets are underdeveloped and SMEs lack the scale, knowledge and skills to approach alternative sources of finance. While bank financing will continue to be crucial for the SME sector across all economies, there is a pressing need to develop a more diversified set of options for SME financing, in order to reduce their vulnerability to changes in credit market conditions, strengthen their capital structure, seize growth opportunities and boost long-term investment. This will also contribute to the resilience of the financial sector and the real economy and to fostering new sources of growth.

4. In the context of its programme of work, the OECD has produced several reports, including policy recommendations, related to these issues. The reports were discussed and declassified by the relevant OECD bodies, and shared with the $\mathrm{G} 20^{26}$. In order to provide a general framework for government action on SME finance, at their meeting in April 2015, the G20 Finance Ministers and Central Banks Governors asked the OECD, together with other relevant international organisations, to develop voluntary high-level principles on SME financing ${ }^{27}$. These principles provide broad guidelines for the development of cross-cutting policy strategies, efforts to benchmark policies and the assessment of current initiatives on SME financing at the local, national and international levels. The principles also aim to encourage dialogue, exchange of experiences and coordination, including regulatory coordination, among stakeholders in SME finance, including policy makers, financial institutions, research institutions and SME management on how to enhance SME access to finance and increase their contribution to resilient and inclusive growth. Further work may involve the identification of effective approaches in G20, OECD and other countries which could facilitate the implementation of the Principles ${ }^{28}$.

5. The present document contains the final version of the principles, which reflect both this G20 request and the ongoing work of the OECD and other international organisations. It benefits from contributions from the OECD Working Party on SMEs and

25 Straight bank debt includes bank loans, overdrafts, credit lines and the use of credit cards. The defining characteristic of straight debt instruments is that they represent an unconditional claim on the borrower, who must pay a specified amount of interest to creditors at fixed intervals, regardless of the financial condition of the company or the return on the investment. The interest rate may be fixed or adjusted periodically according to a reference rate. Straight debt does not include any features other than payment of interest and repayment of principal, i.e. it cannot be converted into another asset, and bank claims have high priority in cases of bankruptcy ('senior debt').

26

See New Approaches to SME and Entrepreneurship Financing: Broadening the range of instruments and SME Debt Financing Beyond Bank Lending: the Role of Securitization, Bonds and Private Placements transmitted to G20 Finance Ministers and Central Bank Governors in February 2015; Financing SMEs and Entrepreneurs 2015. An OECD Scoreboard transmitted to G20 Finance Ministers and Central Bank Governors in April 2015; and Opportunities and Constraints of Market-Based Financing for SMEs transmitted to G20 Finance Ministers and Central Bank Governors in September 2015.

27 It should be noted that the G20 Infrastructure and Investment Working Group (IIWG) and the G20 Global Partnership for Financial Inclusion SME Finance Sub-Group have developed a Joint Action Plan on SME Financing which aims to facilitate dialogue between these groups; extend, as appropriate, successful G20 endorsed reforms and policy measures in G20 and non G20 countries in order to increase the availability of finance for SMEs; and advance the agenda for SME finance across different G20 work streams with a focus on Low Income Developing Countries (LIDCs).

28 Some of the notes to the Principles offer selected examples of some of these approaches, which will be developed in further detail. 
Entrepreneurship, the OECD Committee on Financial Markets, and the G20/OECD Task Force on Institutional Investors and Long-term Financing, and the G20 Infrastructure and Investment Working Group. It also benefits from discussions held in the context of the B20 and the Business and Industry Advisory Committee to the OECD (BIAC). An earlier version of this document was submitted as a draft progress report to the 20-21 August meeting of the G20 Investment and Infrastructure Working Group. It was revised in line with comments received and transmitted to the 4-5 September meeting of the G20 Finance Ministers and Central Banks Governors, who welcomed the progress report in their communiqué. In addition, APEC Finance Ministers welcomed the progress on the development of these principles at their meeting on 11 September. The document was submitted to the G20 Global Partnership for Financial Inclusion (GPFI) at its meeting on 12 September. Another round of consultation, including a stakeholder consultation, took place during the second half of September.

6. The final draft of the Principles was submitted for agreement on 15 October 2015 to the OECD Working Party on SMEs and Entrepreneurship, the OECD Committee on Financial Markets, and the G20/OECD Task Force on Institutional Investors and Longterm Financing, as well as to the G20 Infrastructure and Investment Working Group (IIWG) for any final comments. Taking these comments into account, the final report is now transmitted, as planned, to G20 Leaders.

\section{G20/OECD HIGH-LEVEL PRINCIPLES ON SME FINANCING}

7. These high level principles are addressed to G20 and OECD members and other interested economies, to support their efforts to enhance access to a diverse range of financing instruments by SMEs, including micro-enterprises, and entrepreneurs. The principles are voluntary and non-binding, and build on existing international financial principles and guidelines.

8. Cross-cutting policy strategies to enhance SME access to finance are needed to provide a coherent framework for government actions in this area, within the broader policy ecosystem for SMEs. Such strategies are instrumental to define specific policy objectives; design, coordinate and implement policy measures; and to provide a framework for monitoring and evaluation. ${ }^{l}$

9. The principles that follow may serve the development of such strategies. They can apply to diverse circumstances and different economic, social and regulatory environments. More detailed policy guidance is under development to support governments in operationalising the high-level principles.

\section{Identify SME financing needs and gaps and improve the evidence base}

10. As a first step in developing a strategy to enhance SME access to finance, governments should assess the extent to which SMEs' financing needs are met and where gaps exist, in cooperation with relevant stakeholders, including central banks and financial supervisory authorities, financial and research institutions and SME representatives. This requires a strong evidence base and a better understanding of SME financing needs and challenges by public authorities and financial suppliers. 2 Efforts should be placed on improving statistical information on SME financing, particularly in developing economies, where a lack of reliable evidence constrains policy design, implementation and assessment. This calls for cooperation at the national and 
international levels (including through an expansion of the OECD Scoreboard on Financing SMEs and Entrepreneurs) to increase transparency regarding definitions, improve the comparability of data and indicators, within and across countries 3 , facilitate international benchmarking 4 and regulatory coordination, and shed light on outstanding financing gaps and issues.

\section{Strengthen SME access to traditional bank financing.}

1. As a main source of external finance for most small businesses, efforts to improve banks' capacity to lend to SMEs should be pursued. Measures may include credit guarantees, securitisation5, credit insurance and adequate provisioning for loan losses. Risk mitigation measures should be strengthened, making use of new technologies and mechanisms for underwriting risk67. Effective and predictable insolvency regimes should ensure creditor rights while supporting healthy companies and offering a second chance for honest entrepreneurs. Likewise, SMEs should be afforded credit on reasonable terms and with appropriate consumer protection measures in place. Policy makers should consider enabling SMEs to use a broader set of assets beyond fixed collateral, such as movable assets, to secure loans. The feasibility of expanding the use of intangibles as collateral should be carefully considered, to ease access to lending particularly by knowledge-based companies, while taking into account potential risks. The use of credit information should also be enabled to improve risk management for lenders and access for borrowers.

\section{Enable SMEs to access diverse non-traditional financing instruments and channels}

2. Recognising the complementary nature of the role of banks and other financing channels, access to a sufficiently broad range of SME financing instruments is desirable in order to obtain the form and volume of financing best suited to SMEs specific needs and the stage of the firm life-cycle. Multiple and competing sources of finance for SMEs should be supported, and efforts should be made to increase entrepreneurs' awareness of the available financing options through targeted outreach initiatives. The development of alternative financial instruments for SMEs should also aim to attract a wider range of investors, including institutional investors8, and to enhance their understanding of SME markets. Asset-based finance9 could be fostered to enable young and small firms to access working capital on rapid and flexible terms, as well as supply chain and trade finance to support their integration in global value chains. Alternative forms of debt10 could be cultivated to enable SMEs to invest, expand and restructure. Adequate policy attention should go to the development of hybrid tools 11 and equity instruments 12 to strengthen SMEs' capital structure and boost investment in innovative start-ups and highgrowth SMEs13. Special consideration should be given to venture and private equity financing, including capital for seed, early and later stage investments, as well as to trade finance instruments.

\section{Promote financial inclusion for SMEs and ease access to formal financial services, including for informal firms}

3. Policy should aim to maximise the number of SMEs which have access to and use mainstream financial services and products at a reasonable cost. Financial inclusion is an important tool to reduce informality ${ }^{14}$, and national financial inclusion strategies should include reviewing the legal and regulatory framework of the financial sector; defining a 
public intervention strategy and identifying appropriate delivery instruments; and ensuring the existence of tools for groups excluded from the formal banking sector. ${ }^{15}$ Microfinance schemes should be given adequate attention, particularly in developing countries, as a means to enhance entrepreneurs' access to small amounts of funding at an affordable cost.

\section{Design regulation that supports a range of financing instruments for SMEs, while ensuring financial stability and investor protection}

4. Policy makers and regulatory authorities should ensure that regulation is designed and implemented that facilitates SMEs' access to a broad range of financing instruments without compromising financial stability and investor protection, and enables a return on investment. Regulatory certainty is needed to ensure a predictable and stable operating environment for firms and investors. The combined effects of different regulations should also be considered. Regulations should be proportionate to the risks of different financing instruments. Efforts should be made to avoid undue administrative burdens (including through digitalisation), cut red tape and facilitate bankruptcy resolutions. Particularly in the equity space, flexibility provided to SMEs should be compatible with investor protection, integrity of market participants, corporate governance and transparency. Good corporate governance in SMEs should be encouraged, to enhance their access to equity markets. Legal, tax and regulatory frameworks (including tax policies which provide incentives to encourage both debt and equity financing) should contribute to foster diverse sources of finance. ${ }^{16}$ International regulatory coordination can serve to promote cross-border financing for SMEs. ${ }^{17}$

\section{Improve transparency in SME finance markets}

5. Information asymmetries in finance markets should be minimised to increase market transparency, encourage greater investor participation and reduce financing costs for SMEs. Information infrastructures for credit risk assessment ${ }^{18}$ should aim to support an accurate evaluation of the risk in SME financing. To the extent possible and appropriate, credit risk information should be standardised and made accessible to relevant market participants and policy makers to foster both debt and non-debt SME financing instruments. Accessibility of this information at the international level should be supported to foster SMEs' cross-border activities and participation in global value chains.

\section{Enhance SME financial skills and strategic vision}

6. To enable SMEs to develop a long-term strategic approach to finance and improve business prospects, public policies should champion SMEs' enhanced financial literacy19; their awareness and understanding of the broad range of available financial instruments; and changes in legislation and programmes for SMEs.2021 SME managers should be encouraged to devote due attention to finance issues, acquire skills (including digital skills) for accounting and financial and risk planning, improve communication with investors and respond to disclosure requirements.22 Efforts should also aim to improve the quality of start-ups' business plans and SME investment projects, especially for the riskier segment of the market.23 Programmes should be tailored to the needs and financial literacy levels of different constituencies and target groups, including groups that are underserved by financial markets, such as women, young entrepreneurs, minorities, and entrepreneurs in the informal sector, and to different stages in the SME business cycle. 


\section{Adopt principles of risk sharing for publicly supported SME finance instruments}

7. Public programmes for SME finance should help catalyse and leverage the provision of private resources, especially in risk capital markets. Under certain conditions $^{24}$, public schemes can be effective in kick-starting the offer of financing tools for SMEs. Nevertheless, leveraging private resources and competencies may be essential to enhance the resilience ${ }^{25}$ of SME financing in the face of rapid economic and regulatory change. Policies should aim at encouraging the participation of private investors and developing appropriate risk-sharing and mitigating mechanisms with private partners which ensure proper functioning of public measures, including the allocation of government resources to their most efficient use. Policies should also be designed to avoid "moral hazard", i.e. excessive risk-taking against the public interest, and potential crowding-out effects. ${ }^{26}$ Multilateral development banks (MDBs), national development banks (NDBs) and other public funds should be encouraged to promote SME financing, directly and indirectly.

\section{Encourage timely payments in commercial transactions and public procurement}

8. Timely payments in Business to Business (B2B) and Government to Business (G2B) transactions could be encouraged to enhance the cash flow of small business suppliers. Policy makers and regulators should ensure that SMEs, which are particularly vulnerable to late payments or non-payment ${ }^{27}$, are offered clear and appropriate payment terms. Norms could be designed, implemented and enforced to discourage late payments in commercial transactions, including for cross-border trade. ${ }^{28}$

\section{Design public programmes for SME finance which ensure additionality, cost effectiveness and user-friendliness}

9. The design of public programmes to enhance SME access to finance should ensure financial and economic additionality ${ }^{29}$, along with cost effectiveness. Policy coherence $^{30}$ across levels of government and between government and non-government bodies dealing with SME finance should be pursued, based on reliable evidence. The target population, eligibility criteria, credit risk management and fees structure should be considered carefully and defined clearly when designing programmes, which should be easy to understand for SMEs. The administrative burden and compliance costs of new and existing policies, should be proportionate to the service provided, the impact on beneficiary firms and the broader economy, as well as to the nature and size of the targeted businesses.

\section{Monitor and evaluate public programmes to enhance SME finance}

10. Monitoring and evaluation of policies to ease SMEs' access to finance should be promoted. Ex ante and ex post evaluation should be performed regularly based on clearly defined, rigorous and measurable policy objectives and impacts and in co-operation with financial institutions, SME representatives and other stakeholders. Evaluation findings should feed back into the process of policy making, in particular when measures fail to meet their stated objectives or are found to have undesirable impacts. Regional, national and international policy dialogue and exchange of experiences on how to monitor and evaluate public programmes to enhance SME finance should be encouraged. 
1 Strategies may be developed at various geographical and sectoral levels.

2 Evidence on SME financing, including micro data and micro analysis is needed for informed policy discussion; the evaluation of policies; monitoring the implications of financial reforms on SMEs' access to finance and for a better understanding by financial suppliers' of SME financing needs. Evidence on financing needs and gaps by firm size and stage in the firm life cycle is especially important to tailor policy strategies. In this regard, regular quantitative demand-side surveys can represent an important source of information, but their harmonisation at the national, regional and international level should be encouraged to improve the quality of information and cross-country comparability.

3 At the international level, comparison of data on SME finance is significantly hampered by differences in definitions and methodology.

$4 \quad$ Strengthening the ability to document differences in SME access to finance across countries can shed light on policy experiences and facilitate the exchange and adaptation of good policy practices.

$5 \quad$ High-quality, transparent and standardised securitization of SME loans is one means to strengthen banks' balance sheets and foster their lending to SMEs.

6 To gather more accurate information about businesses, banks may also make use of external experts, particularly for technology-based business models.

$7 \quad$ The use of credit scoring models may also serve to facilitate bank lending to MSMEs by reducing costs and increasing service levels.

$8 \quad$ See also the G20/OECD High level Principles of long term investment financing by institutional investors and their related effective approaches.

9 Asset based finance includes, for example, asset-based lending, factoring, purchase order finance, warehouse receipts, and leasing.

10 Alternative forms of debt include corporate bonds, private placements, direct lending by non-bank institutions, and peer-to-peer lending.

11 Hybrid instruments include subordinated loans and bonds, silent participations, participating loans, profit participation rights, convertible bonds, bonds with warrants, and mezzanine finance

12 Equity instruments comprise venture capital, business angel investing, other private equity instruments, specialised platforms for public listing of SMEs and equity-based crowdfunding

13 The existence of appropriate channels for exit can help increase the attractiveness of these instruments for investors.

14 Informal enterprises are defined on a country specific basis as the set of unincorporated enterprises owned by households which produce at least some products for the market but which either have less than a specified number of employees and/or are not registered under national legislation referring, for example, to tax or social security obligations, or regulatory acts.

15 To promote financial inclusion, the introduction of technological platforms which enable the delivery of a broad variety of financial products and services, drive down the costs of financial access and reach previously untapped markets could be considered.

16 This may be of particular importance to attract private investors to early stage investments.

17 In addition, international exchange of experiences on regulation for new sources of finance can be particularly beneficial.

18 Credit bureaus or registries or data warehouses with loan-level granularity may be part of the information infrastructures for credit risk assessment. 
Financial literacy is defined as a combination of awareness, knowledge, skill, attitude and behaviour necessary to make sound financial decisions and ultimately achieve financial wellbeing by the OECD/International Network on Financial Education (INFE) and G20.

20 The OECD/INFE on financial education for micro, small and medium enterprises has developed work in this area which can provide additional guidance. See also the OECD/INFE High Level Principles on National Strategies for Financial Education endorsed by G20 Leaders in 2012.

21 SME awareness about alternative lending options should also be improved, to enable them to obtain the most favourable credit terms and conditions.

22 Efforts should be made to improve awareness and understanding by SMEs of the information required by creditors and other investors in order to consider their demand for finance. This should include feedback from financial institutions on how to improve the quality of applications for external financing. Entrepreneurs' financial literacy and skills can be improved either through the education system, as part of a more general effort to teach entrepreneurship skills, or through specific programmes and advocacy, including in cooperation with the private and not-for-profit sector. Approaches such as training, mentoring and coaching can help SMEs understand how different instruments serve different financing needs at specific stages of the life cycle; the advantages and risks implied; the complementarities and possibility to leverage different sources of finance; and how to approach different types of investors and meet their information requirements.

23 Investment readiness programmes can support start-ups and SMEs in understanding investors' specific needs, gathering information and developing business plans so as to address these needs appropriately. Furthermore, accompanying support to financing, such as mentoring and coaching, including by investors, can improve the survival and growth of new and small firms.

$24 \quad$ Public policy may be essential to maintain offer of finance to SMEs under certain conditions, such as economic crises or natural disasters. Due to information asymmetries, public policy may also be important to kick-start or boost offer of financial products and services to specific types of SMEs and entrepreneurs, which are typically underserved by financial markets, including young and growth-oriented enterprises.

25 Resilience is the capacity of individuals, communities and systems to resist, adapt, and grow in the face of stress and shocks. Resilience involves being prepared for uncertainty, but also developing the capacity to cope with change and emerge stronger than before.

26 Mechanisms for the development of effective public-private partnerships in SME financing may include co-investment schemes, private-public equity funds, the delivery of public support through private sector intermediaries and the provision of credit guarantees where risks are shared by the public and private sector.

27 Late payments typically force SMEs to seek external finance in order to cover cash flow gap and/or to cut back investment and hiring plans.

28 Possible policy actions to encourage timely payments in commercial transactions include the restriction of the contractual freedom to pay invoices, the automatic entitlement to compensation for late payments, the possibility for SMEs to challenge unfair terms and practices, and the simplification of debt recovery procedures, including for transnational transactions.

$29 \quad$ Financial additionality means that public support reaches viable enterprises which would not otherwise have had access to finance or would have accessed finance at tighter conditions (e.g. higher financing cost, shorter debt maturity). Economic additionality implies that the intervention produces a net positive impact on the economy.

30 Policy coherence is defined as the systematic promotion of mutually reinforcing policy actions across government departments and agencies creating synergies towards achieving the agreed objectives. Within national governments, policy coherence issues arise between different types of public policies, between different levels of government, and between different stakeholders. 
htp://dx.doi.org/10.1787/329168b6-en

\begin{abstract}
Koreen, M., A. Laboul and N. Smaini (2018), "G20/OECD Effective Approaches for Implementing the G20/OECD
High-Level Principles on SME Financing", OECD SME and Effective Approaches for Implementing the G20/OECD
High-Level Principles on SME Financing", OECD SME and Entrepreneurship Papers, No. 9, OECD Publishing, Paris, http://dx.doi.org/10.1787/329168b6-en
\end{abstract}

